Pontifícia Universidade Católica DO RIO DE JANEIRO

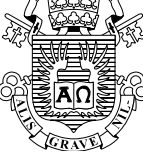

Úrsula Nascimento da Rocha Branco

\title{
NOVAS GESTÕES EMPRESARIAIS POR PROCESSOS: trabalho decente ou trabalho precário?
}

Dissertação de Mestrado

Dissertação apresentada ao Programa de PósGraduação em Serviço Social da PUC-Rio como requisito parcial para obtenção do grau de Mestre em Serviço Social

Orientador: profa. Inez Terezinha Stampa 
Pontifícia Universidade Católica $_{\text {a }}$ DO RIO DE JANEIRO

Úrsula Nascimento da Rocha Branco

\section{NOVAS GESTÕES EMPRESARIAIS POR PROCESSOS: trabalho decente ou trabalho precário?}

Dissertação apresentada como requisito parcial para obtenção do grau de Mestre pelo Programa de PósGraduação em Serviço Social do Departamento de Serviço Social do Centro de Ciências Sociais da PUCRio. Aprovada pela Comissão Examinadora abaixo assinada.

Profa. Inez Terezinha Stampa

Orientador

Departamento de Serviço Social - PUC-Rio

Profa. Lobélia da Silva Faceira

UNIRIO

Prof. Márcio Eduardo Brotto

Universidade do Grande Rio

Profa. Mônica Herz

Vice-Decana de Pós-Graduação do Centro de Ciências Sociais - PUC-Rio

Rio de Janeiro, 20 de agosto de 2013 
Todos os direitos reservados. É proibida a reprodução total ou parcial do trabalho sem autorização da universidade, do autor e do orientador.

\section{Úrsula Nascimento da Rocha Branco}

Graduou-se em Serviço Social pela Universidade do Estado do Rio de Janeiro em 2003. Participou, como bolsista de aperfeiçoamento, do Programa de Estudos do Trabalho e Reprodução Social e, como pesquisadora, do Grupo de Estudos em Serviço Social, Saúde, Trabalho e Meio Ambiente, ambos da Faculdade de Serviço Social da Universidade do Estado do Rio de Janeiro. Atualmente é assistente social do Grupo Eletrobrás. Tem experiência na área de Serviço Social, com ênfase em estudos sobre o Trabalho.

Ficha Catalográfica

Branco, Úrsula Nascimento da Rocha

Novas gestões empresariais por processos: trabalho decente ou trabalho precário? / Úrsula Nascimento da Rocha Branco ; orientadora: Inez Terezinha Stampa. 2013.

$88 \mathrm{f}$ : : il. ; $30 \mathrm{~cm}$

Dissertação (mestrado)-Pontifícia Universidade Católica do Rio de Janeiro, Departamento de Serviço Social, 2013.

Inclui bibliografia.

1. Serviço social - Teses. 2. Reestruturação produtiva. 3. Gestão por processos. 4. Trabalho precário. 5. Trabalho decente. I. Stampa, Inez Terezinha. II. Pontifícia Universidade Católica do Rio de Janeiro. Departamento de Serviço Social. III. Título. 
Dedico este trabalho à minha família, que me apoiou nos momentos mais difíceis da vida. Às minhas filhas Beatriz e Luiza, certa de que qualquer esforço em busca da vitória será sempre por elas. 


\section{Agradecimentos}

Durante essa jornada muitas pessoas estiveram presentes, compartilhando minhas ideias. Porém, algumas foram especiais para a conclusão deste trabalho:

Minhas filhas Beatriz e Luíza, por compreenderem a ausência da mamãe nas brincadeiras durante esse período.

À minha mãe e tia Maria, meus braços direito e esquerdo na administração do meu lar, o que me possibilitou retornar aos estudos.

À Margareth Hisse, minha psicóloga e uma querida, que me deu grande apoio emocional e incentivou minhas ideias, mesmo as mais loucas.

À empresa X, seus gerentes e empregados, que acreditaram no potencial da pesquisa realizada, ainda que discordando de alguns pontos. Sou grata pela oportunidade e pela atenção que me dispensaram.

À minha "escola prática", Alcenir Portella, Martha Lessa, Valesca Losanoff, Therezinha Martinez e Roberta Coelho, assistentes sociais que terei como referência durante toda a minha jornada profissional.

À Prof ${ }^{a}$. Dra . Inez Stampa, que acreditou na realização deste estudo quando nem eu mesma acreditava.

À PUC-Rio e ao Departamento de Serviço Social, pela oportunidade de conviver com pessoas competentes em todas as áreas, que contribuíram com o saber adquirido e para o meu aprendizado.

À Professora Lúcia Freire, por me apresentar, academicamente, ao "mundo do trabalho".

À Banca Examinadora: Prof. Dr. Marcio Eduardo Broto e Prof ${ }^{a}$. Dr ${ }^{a}$. Lobélia da Silva Faceira, que trataram o trabalho com muito carinho e competência, desde o processo de qualificação. 


\section{Resumo}

Branco, Ursula Nascimento da Rocha; Stampa, Inez Terezinha. Novas gestões empresariais por processos: trabalho decente ou trabalho precário? Rio de Janeiro, 2013. 88p. Dissertação de Mestrado Departamento de Serviço Social, Pontifícia Universidade Católica do Rio de Janeiro.

Esta dissertação trata sobre as modificações que o trabalho vem sofrendo a partir do processo de reestruturação produtiva praticado no Brasil desde a década de 1990, visando compreender melhor as alterações em curso, especialmente no que se refere às "novas gestões empresariais baseadas em processos". Neste sentido, buscou conhecer a gestão por processos e sua relação com a organização do trabalho, tomando como exemplo uma empresa do setor elétrico brasileiro. Ressalta-se que tal modelo de gestão teve início, no setor, em 2012, com a reorganização da estrutura empresarial, desde a área de negócios até a gestão de recursos humanos. A pesquisa buscou analisar, também, a chamada "reestatização" do setor elétrico, associada a um movimento de aceleração do crescimento incrementada por exigências de competências e adventos tecnológicos, dada a sua posição estratégica para a economia e o acesso à energia pelos brasileiros. Da mesma forma, objetivou investigar a mobilidade gerada pelo modelo de gestão de processos, imposta aos trabalhadores, enquanto possibilidade de trabalho precário ou trabalho decente. A abordagem teórico-metodológica adotada pautou-se no conceito de trabalho decente como o direito a ter trabalho e de mantê-lo com dignidade e proteção social, tomando-se o trabalho precário como contraposição ao trabalho decente, isto é, como aquele que promove a redução ou suspensão dos direitos. Para tanto, foram realizados contatos com os gestores e com os trabalhadores da empresa estudada, de forma a se compreender a possibilidade de existência do trabalho decente em meio a uma mudança nos padrões de produção e organização do trabalho, onde a palavra de ordem é "otimização", uma vez que a implementação da gestão por processos significa a possibilidade de tornar a empresa mais competitiva no mercado, através da otimização de custos e consequente aumento da eficiência na produção de energia 
elétrica. Os resultados da pesquisa indicaram que a empresa vem operando profundas modificações para atender às exigências do mercado, de forma ágil. Com isso, verificou-se uma diminuição considerável de gastos, principalmente na área de pessoal, com promoção de cortes no orçamento, desenvolvendo, dessa forma, um plano de incentivo à demissão de funcionários terceirizados, o que torna o trabalho decente uma possibilidade ainda distante de se realizar.

\section{Palavras-chave}

Reestruturação produtiva; Gestão por processos; Trabalho precário; Trabalho decente. 


\section{Abstract}

Branco, Ursula Nascimento da Rocha; Stampa, Inez Terezinha (Advisor). New business processes managements: decent work or precarious work? Rio de Janeiro, 2013. 88p. MSc. Dissertation - Departamento de Serviço Social, Pontifícia Universidade Católica do Rio de Janeiro.

This dissertation discusses the changes that work has suffered since the restructuring process practiced in Brazil since the 1990s, intending to understand better the transformations underway, especially those which are related to new "corporate managements based processes". The research sought to understand business process management and its relation to the organization of work, through the case study of a Brazilian public electrical company. It is worth emphasizing that this management model started in this sector in 2012 with the reorganization of the company structure, from the business departments to human resource management. The research also sought to analyze the so-called "renationalization" of the electricity sector associated with accelerating growth by increased demands for skills and technological advances, due to the strategic position of the economy and the access to energy for Brazilians. Equally, we aimed to investigate the mobility generated by this business process management model, imposed on work, and on those who only need their work to survive, through precarious or decent work. The methodological approach adopted was based on the concept of decent work as the right to work with dignity and social protection, seeing precarious work as the opposite of decent work, in other words, as one that promotes the reduction or suspension of rights. With this objective contacts were made with the managers and workers of the company studied in order to understand the possible existence of decent work during the changes in patterns of production and organization of work, where the buzzword is "optimization", as the implementation of process management means the ability to make the company more competitive in the market, by optimizing costs and consequently increasing efficiency in electricity production. The research results indicated that the company carries out profound transformations in order to attend to market requirements in an agile way. With this, a considerable decrease in 
spending mainly in personnel was clear, with promotion of spending cuts, developing, a plan which incentivized the redundancy of outsourced workers, making decent work a distant dream to be achieved.

\section{Keywords}

Productive restructuring; Business process management; Precarious work; Decent work. 


\section{Sumário}

Introdução

1. Modificações recentes no mundo do trabalho:

respondendo as crises do capitalismo

2. Trabalho precário e trabalho decente: fundamentos

para a reflexão

2.1. Novos estatutos de trabalhadores para atender novos modelos de produção

2.2. O trabalho precário como fonte de exploração e perdas subsequentes do direito ao trabalho e do trabalho

2.3. Onde está o trabalho decente? Origem e conceitos

3. O setor elétrico brasileiro e o mercado competitivo financeiro

3.1. Breve história do setor elétrico brasileiro e sua entrada no mercado competitivo financeiro

3.2. A necessidade de reestruturar para se manter produtiva: sobre a gestão por processos na empresa $X$

4. A representação da nova gestão na relação capital trabalho: a pesquisa de campo

4.1. As modificações geradas na empresa $X$ a partir das exigências do mercado

4.2. A concepção da gestão por processos pelo olhar dos entrevistados

4.3. A representação do trabalho diante da gestão por processos

4.4. Como fica o trabalhador? 
6. Referências Bibliográficas

7. Anexos 84

7.1. Anexo 1 - Organograma 1 da empresa X, de 84 dezembro de 2012 julho de 2013

7.3. Anexo 3 - Roteiro de entrevista 86

7.4. Anexo 4 - Termo de Consentimento Livre e 87 Esclarecido (TCLE)

7.5. Anexo 5 - Tabela comparativa de benefícios

88 adquiridos através doAcordo Coletivo de Trabalho (ACT) 


\section{Lista de Siglas}

ABNT - Associação Brasileira de Normas Técnicas

ACT - Acordo Coletivo de Trabalho

AHTD - Agenda Hemisférica do Trabalho Decente

Al 5 - Ato Institucional $\mathrm{n}^{\circ} 5$

AMFORP - American \& Foreign Power Company

ANDT - Agenda Nacional de Trabalho Decente

ANEEL - Agência Nacional de Energia Elétrica

BNDES - Banco Nacional de Desenvolvimento Econômico e Social

CEMIG - Companhia Energética de Minas Gerais

CF/88 - Constituição Federal de 1988

CNAEE - Conselho Nacional de Águas e Energia Elétrica

CNE - Comando Nacional dos Eletricitários

CNPE - Conselho Nacional de Minas e Energia

CONCLAT - Conferência Nacional das Classes Trabalhadoras

CCQ - Círculos de Controle de Qualidade

CQT - Controle de Qualidade Total

CTRI - da Comissão Tripartite de Relações Internacionais

DIEESE - Departamento Intersindical de Estatística e Estudos Socioeconômicos

ELETROBRAS - Centrais Elétricas Brasileiras S. A.

FMI - Fundo Monetário Internacional

FURNAS - Eletrobras Furnas (Furnas Centrais Elétricas S.A.)

GTT - Grupo de Trabalho Tripartite do Governo Federal

IBGE - Instituto Brasileiro de Geografia e Estatística 
LIGHT - Light Serviços de Eletricidade S.A.

MME - Ministério das Minas e Energia

MP - Medida Provisória

MTE - Ministério do Trabalho e Emprego

OIT - Organização Internacional do Trabalho

PAC - Programa de Aceleração do Crescimento

PDE 2019 - Plano Decenal de Expansão de Energia

PND - Programa Nacional de Desestatização

PNETD - Plano Nacional de Emprego e Trabalho Decente

SPE - Sociedade de Propósito Específico

SP RAILWAY - São Paulo Railway, Light and Power Ltda.

TCLE - Termo de Consentimento Livre e Esclarecido

TCU - Tribunal de Contas da União

TEs - Tarifas de Energia

TUSDs - Tarifas de Uso dos Sistemas de Distribuição 
"[...] o movimento do capital é insaciável". Karl Marx, O Capital 


\section{Introdução}

O presente estudo analisa o significado das novas carreiras e percursos profissionais emblemáticos da "sociedade da informação" (Castells, 1999), principalmente os novos contornos assumidos pela organização do trabalho por projetos e gestão de processos, tomando como referência uma determinada empresa do setor elétrico brasileiro, que chamaremos aqui de empresa $X$.

O capitalismo contemporâneo tem como tendência a formação de empresas cujo quadro hierárquico é reduzido e suas unidades são autônomas e organizadas por projetos.

Para os trabalhadores, é requerida capacidade de adaptação constante, de flexibilidade e capacidade de mobilidade no mercado de trabalho, principalmente para atender a dinâmica quase instantânea de novas tecnologias. Estas, por sua vez, exigem deste trabalhador "moderno" uma flexibilidade e capacidade de adaptação a novos projetos em períodos curtos, que Sennett (2006) chama de "trabalho curto por tarefa", com o que Chiapello (2009) concorda ao apontar o acúmulo de experiências que a nova fase do capitalismo impõe a esse também "novo trabalhador", exigindo uma dinâmica que permite acúmulos de experiências. Contudo, seja pelas novidades tecnológicas ou pelo capitalismo "reinventado", uma questão se coloca: o trabalho não está se reinventando para evoluir, está sendo reinventado para servir, ou ainda, se reinventando para sobreviver?

A pesquisa hora apresentada, compreende também um período onde verificamos uma "reestatização" desse mesmo setor elétrico, que vem ocorrendo desde o final do século $X X$ e se mantém no início do século $X X I$, mais precisamente do final da década de 1990 a 2012, onde ocorreu um movimento de aceleração do crescimento deste setor, porém, incrementada por exigências de competências e adventos tecnológicos que também trouxeram consequências para as organizações e seus processos, para o trabalho e para aquele que encontra na venda da força de trabalho o único meio de sobrevivência.

Assim, investigamos a implementação deste novo modelo de gestão e sua relação com 0 trabalho, na empresa $X$ do setor elétrico brasileiro, 
observando que nos dois últimos anos seu quadro gerencial foi reduzido, assim como determinados cargos foram extintos, começando a estimular alguns setores a organizar-se por projetos, o que pode estar transformando o plano de cargos e carreiras deste setor.

O que quisemos conhecer e analisar em nosso estudo é a gestão por processos, seus objetivos, e o quanto este novo modelo vem influenciando a organização do trabalho, bem como os seus impactos para os trabalhadores. Consequentemente, buscamos investigar, ao tomarmos como exemplo uma empresa do setor elétrico, as transformações deste setor até chegar ao patamar de empresa competidora no mercado financeiro, sendo ela uma empresa estatal. Observa-se, portanto, que este estudo não é conclusivo, por se tratar de um processo lento, de mudança de cultura e enquadramentos que ainda não foram completamente implementados.

Para encaminhar o estudo aqui apresentado, tomamos como exemplo uma das empresas que compõem o sistema elétrico brasileiro, buscando desnudar as modificações que ela vem sofrendo e como estas vêm interferindo no trabalho, tendo como eixo de análise a questão do direito ao trabalho e do direito do trabalho.

O recorte temporal para este estudo começa, portanto, no ano 2000 e se estende até o ano de 2013, abarcando elementos que merecem atenção para entendermos o que ocorre nos dias atuais com a empresa $X$.

Tal preocupação surgiu a partir da vivência no campo como estagiária de Serviço Social, no período janeiro de 2000 a outubro de 2003, que se tornou, nessa mesma época, minha primeira experiência profissional, que completou doze anos em 2012. Estou atuando como assistente social na referida empresa desde então, o que vem me permitindo observar as mudanças antes referidas desde o início do governo Lula (2003-2010), as quais vêm se intensificando nos últimos dois anos (2011-2013).

Para apresentar este trabalho começaremos pelo capítulo primeiro, onde procuramos resgatar as estratégias do capital no enfrentamento de suas crises, demonstrando a capacidade deste sistema em criar novos mecanismos de controle da vida social em prol da acumulação. Apresentamos um breve panorama histórico como base teórica das análises desenvolvidas a partir do olhar dos entrevistados na pesquisa de campo, que será apresentada no capítulo quarto. 
No segundo capítulo apresentamos as transformações do trabalho ao longo das diversas estratégias capitalistas demonstradas no capítulo 1 , analisando o quanto a gestão do trabalho foi sendo modificada nesse mesmo período, que vai da era fordista às reinvenções tayloristas, bem como a própria gestão por processos, que traz em seu escopo características muito similares às encontradas no toyotismo japonês, como a valorização de uma divisão do trabalho mais dinâmica, flexível e fragmentada.

O capítulo terceiro aborda a história do setor elétrico brasileiro e da empresa de referência para esta pesquisa, passando pelas suas transformações históricas que desembocaram na "necessidade" de implantar a gestão por processos, parte da estratégia de reestruturação na sua produção para atender as novas exigências do mercado competitivo de energia elétrica.

O capítulo 4 finalmente apresenta os dados e análises de um estudo realizado com 10 trabalhadores, sendo: 6 trabalhadores ligados diretamente às novas exigências da gestão por processos, 2 gerentes envolvidos na implementação desta e 2 sindicalistas representando os interesses da classe trabalhadora, seja ela efetiva ou contratada. Para dar visibilidade aos entrevistados sem, contudo, expô-los, adotamos, para identificá-los nesta dissertação, a designação trabalhador $1,2,3,4,5$ e 6, sindicalistas A e B e gerentes $Y$ e $Z$. Assim como a identidade da empresa em questão será preservada através do codinome $X$. Desta forma, buscamos respeitar os princípios éticos da pesquisa científica, qualificando os sujeitos participantes, mas resguardando suas identidades.

A metodologia utilizada refere-se à análise qualitativa e análise documental. A análise documental esteve voltada para o resgate da história da empresa e de exame da documentação do sindicato referente aos acordos coletivos dos últimos 13 anos.

A abordagem dos sujeitos participantes e a condução das entrevistas foi baseada em Mayring (2002), com a utilização da técnica identificada como entrevista centrada no problema. Ela permite realizar entrevistas semiestruturadas, abertas e direcionadas para uma problemática determinada pelo entrevistador, valorizando-o durante a entrevista, de forma a não sair do eixo central do tema. O mais importante nesta técnica é centrar o problema no objeto e no processo. 
Por fim, buscou-se, com este estudo, investigar as possibilidades de convivência do trabalho decente com as novas estratégias adotadas para a gestão do trabalho. Neste sentido, e conforme preconizado pela Organização Internacional do Trabalho (OIT), o trabalho decente é aqui identificado como um conjunto de medidas onde se estabelecem melhores condições de trabalho e diminuição do desemprego. A investigação se deu a partir da experiência de reestruturação da empresa $X$, que vem adotando como metodologia a gestão por processos. Tal estratégia consiste na adoção de medidas que visam tornar a empresa mais competitiva no mercado, através da otimização de custos e consequente aumento da eficiência na produção.

Não se pretendeu, com este trabalho, responder de forma definitiva se haverá ou não trabalho decente após a implantação completa da nova forma de gestão na empresa $X$. O que buscamos foi questionar, com base teórica e metodológica, se existe possibilidade de trabalho decente diante de estratégias que buscam acumular cada vez mais capital, tomando como referência os novos modelos de gestão, como a adotada na empresa X. 


\section{1 Modificações recentes no mundo do trabalho:
respondendo as crises do capitalismo}

A nova proposta de reformulação do capitalismo, tendo em vista o esgotamento dos modelos "fordista" e "taylorista" de acumulação, teve como pilar de sustentação um novo modelo que se incorpora aos anteriores e logo ganha identidade própria diante da sua necessidade de aumentar cada vez mais o lucro e, consequentemente, a acumulação de capital.

Surge, então, a acumulação flexível, orientada pelo modelo japonês, denominado "toyotismo", responsável pelos novos processos de trabalho e flexibilização da produção, que passa a atender as necessidades do mercado de forma gradual, ao invés da produção em massa própria ao modelo "taylorista". Este modelo, esgotado pela crise estrutural do capitalismo, evidenciada na queda da taxa de lucro, devido ao preço elevado da força de trabalho, conquistado no pós-45 e pelas lutas sociais da década de 60 , que defendiam a socialização da produção.

Contudo, o que ocorreu foi uma retração do consumo devido ao desemprego estrututral que já se configurava. Ou seja, esse sistema já dava sinais de cansaço e apontava para a necessidade de reformulação diante do esgotamento da forma de exploração vigente em prol da acumulação de capital.

Com base em Antunes:

A crise capitalista não é outra coisa senão a ruptura de um padrão de dominação de classe relativamente estável. Aparece como uma crise econômica, que se expressa na queda da taxa de lucro. Seu núcleo, entretanto, é marcado pelo fracasso de um padrão de dominação estabelecido. (...) Para o capital, a crise somente pode encontrar sua resolução através da luta, mediante o estabelecimento da autoridade e através de uma difícil busca de novos padrões de dominação (Antunes, 1999, p. 31).

A crise aqui analisada estava enraizada na questão financeira, que ganhava cada vez mais autonomia no interior das relações existentes no mercado e no seu processo produtivo, tendo como cenário uma 
desregulamentação generalizada que passava pelo comércio, tecnologia e pelas condições de trabalho e emprego.

Esse processo expansionista começa a frear no pós-guerra, quando a desregulamentação atinge os capitais produtivos transnacionais e não só os capitais financeiros especulativos. Começa, então, a reorganização da produção e com ela as "novas formas de domínio técnico-científico", tendo como liderança um seleto grupo de países capitalistas avançados, ficando para trás aqueles de industrialização tímida, ou, ainda os chamados de "terceiro mundo", completamente dependentes e dominados (Antunes, 1999, p.33).

Enquanto a década de 80 caracterizava-se por uma crise nos países centrais, principalmente do leste Europeu e os EUA, a década de 90 foi tomada por uma crise generalizada entre os outros países, principalmente na Ásia e no Japão, que funcionaram como vitrine do capitalismo global na década de 80 e início da década de 90,

O que vimos foram países tentando acompanhar o ritmo imposto pelo "capitalismo avançado" desses países centrais, mas sem condições de igualdade competitiva de mercado e avanços tecnológicos, mantendo alguns países, antes centrais, cada vez mais periféricos em relação ao movimento de "reposição dos capitais" que, particularmente, tem como maior consequência o desemprego e a precarização da mão de obra. Sobre isso, vejamos: “(...) há também, em escala mundial, uma ação destrutiva contra a força humana de trabalho, que tem enormes contingentes precarizados ou mesmo à margem do processo produtivo, elevando a intensidade dos níveis de desemprego estrutural" (Antunes, 1999, p. 33).

O que percebemos ao longo da história do capitalismo é uma lógica que, para sanar suas crises, subtrai sempre da classe trabalhadora o máximo de sua força de trabalho, prolongando-a ao limite e respondendo a competitividade cada vez mais acentuada no mercado.

Associado a isso, existe a degradação na relação entre o homem e o ambiente, que também se torna destrutiva, na medida em que a produção não estabelece limites para o estímulo do consumo. Esse ciclo agride a relação do homem com o meio ambiente, e a natureza é cada vez mais explorada, em prol do processo de valorização do capital. Contudo, as soluções são buscadas por esse sistema de diversas maneiras, mas o seu pilar de sustentação continua o mesmo, mantendo com isso seu padrão de produção. 
Vimos no fordismo e taylorismo mecanismos de acumulação diversos, porém, sua lógica e padrão permanecem, não obstante as novas formas de gestão da produção e do trabalho que são adotadas. Ainda que tenha havido lutas intensas na década de 60 , elas não foram suficientes para estruturar uma frente contra o capital e a favor do trabalho, se mantendo, este último, submisso a ele, obedecendo às novas reestruturações no modo de produção a que está submetido.

É importante ressaltar aqui as principais características deste padrão de produção, para que desenhemos mais adiante as modificações sofridas por ele até chegar às crises contemporâneas do capitalismo, que surgem na segunda metade do século $X X$.

A característica principal do fordismo/taylorismo está em combater o desperdício na produção e produzir mais com menos, o que significa, em termos de força de trabalho, mais exploração, de forma verticalizada e produção em massa. Nesse modelo, a produção era ainda caracterizada pela atividade fragmentada que resultava, pelo trabalho coletivo, na geração de um produto, no caso da fábrica Ford, dos veículos.

Dessa forma, o trabalho ficava reduzido a um pedaço da máquina pertencente à produção, o que facilitava a extração da mais valia, uma vez que permitia o prolongamento da jornada de trabalho, intensificando de forma concisa toda a produção. "A subsunção real do trabalho ao capital, própria da fase da maquinaria, estava consolidada" (Antunes, 1999, p. 37).

A crise do taylorismo/fordismo, iniciada ainda na década de 70 , que conjugou a fragilidade de diversos elementos considerados estruturais para 0 capital, como a queda da taxa de lucro e a retração do mercado consumidor, incentivada pelo desemprego estrutural que então se iniciava, somada ao ideário neoliberal de desregulamentação estatal, foi suficiente para que o sistema desenhasse uma nova estratégia de manutenção do padrão de acumulação.

Obseravmos, nos anos 70, uma nova modificação nos modos de produção e acumulação do capital para reestruturar o sistema de acumulação pós-crise. Para além dessa remodelação, foi importante refazer seu "projeto de dominação societal" (Antunes, 2000, p.18), fortemente contestado pela classe trabalhadora, que confrontava seus mecanismos de controle social. 
O capital pôs em prática as transformações, constituindo novas formas de acumulação flexível, a partir de incrementos tecnológicos e nova gestão organizacional, dando vida ao modelo japonês de produção, o toyotismo. Este nasce da consequência de disputas que vinham ocorrendo no interior do capitalismo, entre empresas transnacionais e monopolistas. Por outro lado, representava uma tentativa de controle de classe, controle, sobretudo, do trabalho, o que incrementou uma resposta rápida do capitalismo à sua própria crise.

O toyotismo se caracteriza por várias medidas verificadas no interior da produção, como a gestão participativa e a busca da qualidade total. "Estas são expressões visíveis não só no mundo japonês, mas em vários países de capitalismo avançado e do terceiro mundo industrializado" (Antunes, 2000, p. 24). Neles, o trabalho se organiza em torno do modelo flexibilizado que exige do trabalhador operar em diferentes máquinas (modernizadas), que reivindicam a polivalência e especialização da mão-de-obra em diversas áreas do conhecimento.

A gerência organiza essa mão de obra em equipes responsáveis pelo controle dos seus membros, os quais, estimulados por ganhos extras e compensações, "vestem a camisa" da empresa estruturando uma espécie de dominação consentida, silenciosa. Essa forma de dominação opera uma naturalização das subcontratações e até do desemprego, sob o pretexto de garantir a sobrevivência da equipe.

Nesse contexto, a chamada reestruturação produtiva se deu de diferentes formas no universo globalizado. Teve sua inserção no Brasil no início da década de 80 , devido à necessidade de se adequar aos moldes internacionais, com o objetivo de se enquadrar na busca da produção e qualificação determinadas por tal modelo e, consequentemente, entrar no mercado competitivo.

Em países industrializados como o Brasil, como bem aponta Behring (2001), a reestruturação produtiva se dá "em combinação com o ajuste neoliberal", quer dizer, com base em uma ideologia que tem como característica principal a "desregulamentação de direitos e o corte dos gastos sociais" (Behring, 2001, p. 111). 
A "entrada" da reestruturação produtiva no Brasil, na década de 1990, ganha expressão na conjuntura econômica da época do Plano Real ${ }^{1}$. Esse processo provocou uma avalanche de desemprego, que se configurou de maneira mais desastrosa com a desestatização (leia-se privatização) de empresas estatais, a terceirização de serviços e a precarização do trabalho.

Tendo em vista os novos padrões de gestão adotados pelas empresas do setor elétrico brasileiro, por exigência do mercado competitivo e com base em elementos que acompanham tais mudanças, é possível afirmar que a reestruturação produtiva obedece às imposições do sistema capitalista globalizado e foi adotada como estratégia para sanar mais uma de suas crises.

Dessa forma, a pesquisa aqui proposta assenta-se na hipótese de que as mudanças nas relações de trabalho provocadas por modelos como "fordismo", "taylorismo" e pela "acumulação flexível" acarretaram consequências de diferentes ordens na vida social, econômica e política do Brasil, de forma objetiva e subjetiva. O que importa, nesse momento, é atender às novas necessidades de um mercado criador de diferentes instrumentos que flexibilizam a produção e exigem cada vez mais dos trabalhadores como, por exemplo, os círculos de controle de qualidade (CCQ) e qualidade total, também presentes no setor elétrico brasileiro. Para tanto, é preciso produzir cada vez mais e gastar cada vez menos, flexibilizando a produção em prol do lucro e/ou de resultados positivos na agenda do governo federal.

Como consequência da busca desenfreada pelo lucro observa-se o crescente desemprego estrutural que advém tanto da redução dos pontos de emprego, como da sua precarização, bem expressa em formas diferentes de subcontratação, o que faz com que o trabalhador fique cada vez mais dependente do mercado de trabalho e distante de sua cidadania.

Ao longo da década de 1990 e do início dos anos 2000 percebeu-se um significativo crescimento do trabalho terceirizado e precarizado no Brasil, o que flexibilizou ainda mais os direitos trabalhistas e trouxe consequências nefastas para a saúde daquele que vive do trabalho.

\footnotetext{
${ }^{1}$ O Plano Real foi um programa adotado durante o governo Itamar Franco (1992-1994) visando à estabilização e reformas econômicas. O Programa estabeleceu regras de conversão e uso de valores monetários, iniciou a desindexação da economia e determinou o lançamento de uma nova moeda, o Real. O programa tinha como objetivo principal o controle da hiperinflação que assolava o país.
} 
No âmbito das relações de produção, a saúde é atingida através de um padrão de gestão capitalista que busca no trabalho subjetivado a fonte de obtenção de lucro, utilizando-se de artifícios meritocráticos (premiações) para seduzir e garantir o consentimento do trabalhador. Por outro lado, estes se submetem a sistemas de aprisionamento, tais como o monitoramento de horas trabalhadas, banco de horas com regras rígidas para serem utilizadas, onde o trabalhador sempre está com saldo devedor na empresa. Essa caracterização, segundo Guatarri (1987), pode ser compreendida, "como a principal "engrenagem" a ser desconectada para que se possa apreender os mecanismos de sujeição dos fluxos operários das forças produtivas a uma dada organização do trabalho" (p. 27).

Tomando em conta tais elementos, parece claro que a reestruturação produtiva é um processo econômico, político e cultural em curso, de grande dinamismo e alta complexidade, que acontece em escala mundial e em ritmo intenso, exigindo a inserção de todos. Estruturalmente vinculada à globalização, estes dois processos têm sido conduzidos pelas forças hegemônicas em âmbito internacional, representando a mais recente configuração do capitalismo - a qual converte o sistema mundial em espaço de acumulação - apontando para profundas repercussões sobre a vida social. Daí a importância de estudar este processo, verificar suas reais dimensões; identificar, em essência, suas potencialidades, para buscar interferir nele, através do espaço da empresa, representada aqui pelo setor elétrico.

Ao longo se sua história, o sistema capitalista passou por diversas crises. Afinal, como bem lembra Harvey, "as crises financeiras servem para racionalizar as irracionalidades do capitalismo" (2010, p.10). Isso significa que ele ainda sobrevive às suas próprias crises desde 1929, passando por 1945, e na década de 1970. Porém, nada comparado a 2008, quando os EUA enfrentou a maior crise de todos os tempos, que teve seu presságio anunciado ainda na década de 1990, quando ainda sem muito significado para o Estado e o mercado, por atingir uma "classe social pouco importante", pois "os afrodescendentes, em especial, vinham tendo dificuldades com o financiamento de habitação desde o fim dos anos 90" (Vasapollo, 2005, p. 38).

A crise só assombrou os EUA em outubro de 2008, com a desfragmentação de Wall Street, pois desta vez "os mercados globais de crédito 
congelaram, assim como a maioria dos empréstimos no mundo" (Harvey, 2010, p.10).

O recorte temporal para este estudo começa no ano 2000 e se estende até o ano de 2013, abarcando elementos que merecem atenção para entendermos o que ocorre nos dias atuais com a empresa $\mathrm{X}$, pois o começo dos anos 2000, que abrange o governo Lula, representou um período de crescimento econômico na realidade brasileira, a taxa de emprego com carteira assinada no período entre 2002 a 2009 subiu de 54,02\% para 59,59\% (IBGE, 2010). A partir de 2004 observou-se um crescimento mais intenso, alcançando a taxa de 5,7\%, com o PIB per capta aumentado em 4,3\% nesse mesmo ano. Este crescimento se manteve nos anos seguintes, alcançando em 2007 a marca de 6,1\%, e em 2008, 5,2\%. O Brasil só sentiu os reflexos da crise internacional em 2009, quando seu desempenho teve forte queda. Contudo, as taxas de emprego se mantiveram crescentes, gerando quase um milhão de novos postos de trabalho formal ${ }^{2}$.

O período citado acima, que vai de 2002 a 2009, demonstrou que foi fundamental a isenção de impostos federais sobre produtos industrializados, mantendo uma demanda de consumo alta. No mesmo período foram lançados pacotes de incentivo ao crescimento, e dentre eles estão aportes extras de recursos econômicos para o Banco Nacional de Desenvolvimento Econômico e Social (BNDES); reajuste do salário mínimo e realização de obras importantes como as do Programa de Aceleração do Crescimento (PAC).

Somado a estas medidas houve ainda o equilíbrio das contas públicas, com mudança na composição da dívida pública, o que representou para o ano de 2009 a retomada do crescimento, "Ao contrário de todas as crises anteriores, quando o Estado se tornava insolvente, naquele ano foram recursos públicos que socorreram o setor privado com injeção de credito e outras medidas de caráter fiscal tributário" (Dieese, 2008, p 14).

Ademais, outras medidas como valorização do salário mínimo, programas de transferência de renda e aumento em investimentos públicos facilitaram o crescimento histórico do PIB de 43,7\%, se comparado ao quadro econômico internacional. Dessa forma, o Brasil passa pela primeira década do século XXI com um mercado interno mais forte e com redução de sua vulnerabilidade,

\footnotetext{
${ }^{2}$ Dados referentes aos anos 2000, constantes da Relação Anual de Informações Sociais (RAIS), do MTE.
} 
proporcionando aumento nos índices de emprego formal e, consequentemente, da renda. Contudo, nesse período as taxas de crescimento do emprego, especialmente o formal, foram muito expressivas, em um contexto de poucas mudanças nas relações de trabalho, ou nos fatores internos ao mercado de trabalho, como a educação básica e a qualificação da força de trabalho.

Ao contrário da década de 1990 e dos primeiros anos deste século, período em que a flexibilização das relações de trabalho era enfaticamente defendidas por alguns analistas, dentro e fora do governo federal, como saída para o desemprego e a precarização do trabalho, os anos 2000 se caracterizaram pela ausência de medidas governamentais nessa direção, concentrando esforços na estabilidade da economia brasileira, na continuidade do crescimento econômico e na melhoria dos indicadores do mercado de trabalho.

Não obstante a melhoria desses indicadores e conforme já mencionado anteriormente, o modelo japonês, ou toyotismo, imprimiu uma remodelagem nas relações de produção, propiciando mais flexibilidade na gestão.

Importante lembrar que a partir dos anos 1970 verifica-se, nos países capitalistas centrais, uma transformação no mercado de trabalho, evidenciado por modificações nos diversos setores da economia.

Muitas profissões deixaram de existir, outras surgiram. O setor de serviços cresceu rapidamente em relação aos setores primário e secundário, e os prestadores de serviços (a maioria terceirizados) se multiplicaram. Além disso, o toyotismo facilitou a diminuição do emprego formal em favor de uma crescente onda de trabalho parcial, subcontratações, temporários, estagiários e terceirizados.

Com a acumulação flexível fica visível a constituição de dois grupos distintos de trabalhadores dentro das empresas: um grupo central, composto por trabalhadores "qualificados", cujos salários são relativamente mais altos e cujas tarefas são as consideradas "finalísticas" ou estratégicas para as empresas. De outro lado, um segundo segmento, composto pelos trabalhadores "periféricos", onde se situam os trabalhadores sem vínculo empregatício com a empresa e cujos salários são, em geral, baixos e sem garantias de emprego. Tal grupo realiza as tarefas consideradas "não finalísticas", ou atividades-meio, as que não são estratégicas para a empresa. Este grupo é, frequentemente, composto por terceirizados, subcontratados, temporários e estagiários. 
Com a nova estratégia denominada gestão por processos, percebemos que há um enxugamento do quadro de funcionários, visando otimizar a produção, como a gestão por processos propõe, começando pelos terceirizados, uma vez que seus vínculos empregatícios são fragilizados, o que facilita o seu desligamento. $\mathrm{O}$ que antes era precário passa a nem mesmo existir, gerando o aumento do desemprego.

Porém, existem outros pontos de fragilidade na relação entre as novas formas de gestão e o trabalho, que podem estar embutidos no acúmulo de tarefas delegadas ao empregado (independente de seu vínculo), as orientações dadas sobre como os trabalhadores devem se comportar diante das mudanças para que a gestão alcance seus objetivos, e de que forma um comportamento considerado inadequado pode atrapalhar o processo.

Essa é uma das articulações primordiais para esta pesquisa, na medida em que relaciona o trabalho precário, como aqui exemplificado através da terceirização, entre outras modalidades, as novas formas de gestão e o trabalho decente, investigando quais são as consequências da relação entre tais elementos para o trabalhador, tomando como realidade a empresa X estudada. 


\section{2 \\ Trabalho precário e trabalho decente: fundamentos para a reflexão}

\section{1. \\ Novos estatutos de trabalhadores para atender novos modelos de produção}

Como vimos anteriormente, as reinvenções do sistema capitalista que prolongam sua vida útil interferem de forma direta na organização do trabalho, criando, cada vez mais, categorias de trabalhadores que atendem seus ideais de produção. Cria-se enorme contingente de trabalhadores com diferentes relações patronais, muitas vezes situados em uma mesma empresa. Uma realidade cada vez mais presente no mundo do trabalho hoje, sem contar com o desemprego estrutural, inerente à ordem capitalista.

Pretendemos aqui analisar como se encontra o trabalho na sociedade contemporânea, como já visto aqui, a partir da reestruturação produtiva, momento em que o trabalho sofre seu maior impacto estrutural, analisando de forma mais objetiva e concreta e privilegiando o direito ao trabalho e no trabalho, em momento de desemprego e redução de proteção social. Faz-se necessário pontuar essas questões para mais adiante entendermos como o trabalho veio se modificando ao longo da história da empresa estudada até a sua restruturação.

Compartilhando a visão de Alves (2000), os diferentes estatutos de trabalhadores surgem a partir da mundialização do capital e, no caso do Brasil, com a "chegada" da reestruturação produtiva. Porém, existe um aspecto importante a ser tratado, relacionado diretamente às novas categorias de trabalhadores. Refiro-me à crise no interior das organizações sindicais, fator também motivador de uma crise do mundo do trabalho no Brasil, sobretudo na década de 1990, onde provocou, segundo Antunes (2000,) uma "crise da objetividade" entre a classe trabalhadora.

Com isso, surge, então, uma força de trabalho com o mais alto nível de educação e de qualificação, porém inserida numa classe fragmentada em virtude 
do desemprego estrutural e de salários indignos e trabalhos precarizados. Com isso, perde-se a perspectiva de classe, e sem consciência da importância da união, os trabalhadores se tornam frágeis dentro das células modernas da sociedade do trabalho, provocando uma nova exclusão social. Segundo Alves "é nessa perspectiva que se desenvolve a crise do sindicalismo no Brasil, cujo principal aspecto ideológico - o surgimento de estratégias sindicais neocorporativas de caris propositivo - vincula-se às determinações estruturais da nova crise do mundo do trabalho" (Alves, 2000, p.10).

Sem aprofundar mais sobre este tema, pois nosso objeto de estudo não se refere diretamente aos sindicatos, é importante entender que ao atingir a organização da classe trabalhadora, representada pelo sindicalismo, o trabalho se enfraquece diante da voraz transformação da produção, ficando a mercê do empoderamento das novas formas de produção sobre o trabalho, reduzindo o mesmo aos desmandos do capital. "Uma manipulação que perpassa não apenas a esfera do consumo, mas atinge, com inusitado vigor, a esfera da produção, dissipando nela os vestígios do antagonismo de classe" (Alves, 2000, p. 12).

Percebemos que há um declínio da classe operária industrial, principalmente nos países capitalistas, que se inicia na década de 1970 e se intensifica na década seguinte. Há, nesse momento, uma diminuição do operariado na centralidade da produção, abrindo espaço para um novo proletariado industrial, ainda mais produtivo, porém mais afastado do núcleo da produção, se mantendo periférico, em subcontratações nas indústrias e no setor de "serviços" que, como define Alves, é "um neoproletariado 'pós-moderno', com estatutos sociais precários” (Alves, 2000, p. 15).

Observamos, então, categorias distintas de trabalhadores com a nova divisão do trabalho, uma mais centralizada, atendendo as necessidades do capital que demandam uma maior qualificação e polivalência, e aquela que se posiciona à margem desse processo produtivo, periférico, sem garantias e vivendo um mundo do trabalho de precariedade na "roleta russa" do desemprego.

No Brasil, já na década de 1980 essa lógica esteve presente nas empresas transnacionais, como a indústria automobilística, mantendo o mesmo padrão de produção e exploração, valorizando cada vez mais um processo de racionalização produtiva, própria do ideário toyotista, embutindo ainda novas tecnologias com redução do emprego nas indústrias. 
Esses movimentos não extinguem o trabalho, a tendência, desde a década de 1980, é que haja uma modificação adequada à lógica do capital, tendo como acelerador destas mudanças o toyotismo, sem considerá-lo a principal causa dessas modificações no trabalho.

O que ocorre de maneira mais direta é uma transformação no fazer e no saber do operariado, que reflete fortemente nos direitos dos trabalhadores, nos salários, nas suas reivindicações enquanto classe. Ou seja, constrói-se um novo modo de existir do trabalho assalariado, não acabando com sua essência na relação capital $x$ trabalho, uma vez que "as relações estruturais da sociedade capitalista permanecem fundamentalmente as mesmas” (Mészáros, 1993, p. 91).

Diante da divisão entre categorias de operários, vemos que as funções de organização das indústrias se sobrepõem ao trabalho manual, ficando mais valorizado o trabalho intelectual, e provocando uma divisão na estrutura da classe operária, separando os trabalhadores em operários polivalentes e subproletariado. Com isso, o centro nervoso do trabalho na indústria perde sua materialidade diante das novas organizações, com base nos serviços.

Na era pós-industrial, como aponta Alves (2000), o operário polivalente se destaca como um mero "servidor de um sistema de máquinas". Ele passa a observar o funcionamento das máquinas apenas para certificar seu funcionamento. Surge, então, um novo estranhamento, seguido de um enfrentamento diferente do anterior onde se destacava o trabalho material, surgindo uma nova subordinação do trabalho ao capital a partir do trabalho intelectual.

Durante a "era toyotista" o trabalho se metamorfoseou e criou novas categorias, sem perder, contudo, sua centralidade, que pode ser vista através de trabalhadores subproletarizados, como denomina Alves (2000), ao analisar postos de trabalho assalariado em tempo parcial, temporários ou subcontratados, criando assim uma informalização nas relações de trabalho, incluindo, ainda, o desemprego estrutural. Sobre a subproletarização, argumenta Alves:

Ela é tão importante para a nova ordem do capital quanto o desemprego estrutural. É um aspecto dissimulado da nova exclusão social, do qual o desemprego estrutural é sua fratura exposta, muitas vezes, a discussão da quantidade de empregos sobrepõe-se a da qualidade dos novos postos de trabalho, ocultando, portanto, o problema da subproletarização tardia como um 
dos maiores problemas do mundo do trabalho no limiar do século XXI (Alves, 2000, p.78).

Alves (2000) defende ainda que dentro da nova precariedade do trabalho existem, dentro dos núcleos constitutivos da produção, periférico e central, trabalhadores que respondem às suas necessidades. Na camada periférica da produção como um todo, são facilmente reconhecidos por serem avulsos, subcontratados, ainda que exerçam função de alto nível, são facilmente descartados em tempos de recessão, possuem menos oportunidades de carreira e menos segurança no trabalho. Do outro lado, nos núcleos mais importantes da produção, encontram-se trabalhadores centrais, mais privilegiados no que tange a garantia de emprego, qualificação, gozando de maiores e melhores direitos no trabalho. Este atende de forma flexível e com maior mobilidade.

Ademais, a lógica do toyotismo estimula o crescimento de pequenas empresas (fornecedores ou subcontratadas) no entorno de uma fábrica reduzida, ou lean production. Nelas predomina o trabalho precarizado, diferente do estatuto do trabalho da indústria ou empresa principal. A utilização das pequenas empresas tornou-se uma estratégia de organização industrial voltada para o controle de trabalho e emprego, adequada à nova época de crise de valorização do capital, na qual a instabilidade perpétua impõe a constituição, pelas corporações transnacionais, de uma amparadora de pequenas empresas que minimizam as flutuações dos mercados. "É um componente decisivo para instaurar um novo patamar de flexibilidade do capital num cenário de crise de valorização e de concorrência planetária" (Alves, 2000, p. 81).

\section{2. \\ O trabalho precário como fonte de exploração e perdas subsequentes do direito ao trabalho e do trabalho}

De acordo com Cattani \& Holzmann (2006, p. 203), a definição do termo trabalho precário contempla pelo menos duas dimensões: "a ausência ou redução de direitos e garantias do trabalho e a qualidade no exercício da atividade". Na primeira, considera-se o retrocesso em relação às conquistas 
trabalhistas constitucionais e negociações sindicais; e na segunda, consideramse a relação entre ganhos e quantidade de trabalho e, complementarmente, aspectos ligados diretamente ao exercício da atividade.

A primeira possibilidade de precarização do trabalho, por ausência ou redução de direitos, como explicam citados autores, desenha um universo de desemprego estrutural onde a oferta de emprego é menor do que a disponibilidade de mão de obra no mercado. Cabe avaliar que a maior taxa de desemprego registrada no período da atual metodologia - utilizada pelo Instituto Brasileiro de Geografia e Estatística (IBGE) desde janeiro de 2002 - foi a do mês de abril de 2004 (13,1\%) e a menor foi a de dezembro de 2011 (4,7\%). Somente duas vezes, em 2006 e 2009, a taxa subiu em relação ao ano anterior. Depois de sucessivas altas devido à crise econômica, o desemprego no Brasil voltou a decrescer. Em 2012 a taxa era de 5,5\%.

Seja ela penetrada por diferentes vias no mundo do trabalho, o fato é que a precarização assumiu, ao longo do século $\mathrm{XX}$, faces múltiplas geradas num mesmo processo que busca garantir a competitividade, o que significa ser mais produtivo gastando menos, o que torna a empresa que adquire este tipo de lógica de produção mais atraente para o mercado. Tudo isso somado ao avanço de novas tecnologias que dispensa cada vez mais o trabalho vivo.

A redução dos postos de trabalho vem ocorrendo desde o final do século $X X$, no início da reestruturação produtiva, no Brasil, provocando uma desregulamentação do trabalho enquanto direito, diversificando as relações de trabalho e sua forma de inserção no mercado de trabalho, surgindo formas distintas de contratos de trabalho e assalariamento, dando margem a diversas situações de descumprimento legal, ou, ainda, inserindo o trabalhador no trabalho informal, ou por conta própria, sem qualquer condição de assalariamento ou vínculo. De qualquer forma, os vínculos empregatícios estão cada vez mais frágeis, desfavorecendo a classe trabalhadora, esvaziando sua noção de classe.

Encontramos, ainda, no mundo do trabalho, uma importante estratégia de cunho capitalista, a terceirização, característica já mencionada aqui, com nascedouro na organização toyotista, que estimulava o setor de serviços. Essa foi uma excelente saída das empresas, principalmente das indústrias, para reduzir seus custos, principalmente em tempos de crise, contratando empresas prestadoras de serviços que, segundo Graça Druck, é uma das formas de 
precarização do trabalho mais comum introduzida pelo toyotismo na sua "nova forma de gestão e organização do trabalho" (Druck, 2007, p.7), que dá um caráter flexibilizado às estratégias de gestão empresarial. Ainda de acordo com Druck,

A facilidade de se adaptar às novas exigências produtivas e do mercado, consideradas como inexoráveis e definitivas pelas estratégias empresariais, imprime um caráter flexível à gestão, o que desobriga de tudo que é fixo, rígido ou estável através dos diferentes usos da força de trabalho. Daí a transferência das responsabilidades de gestão para um terceiro (Druck, 2007, p. 7).

$\mathrm{Na}$ medida em que se amplia a questão estrutural do desemprego, estimulado pela falta de mão-de-obra qualificada com condições adequadas ao mercado de trabalho e consumo, torna-se impossível a integração dos diversos segmentos sociais, dilatando, consideravelmente, a barreira imposta à grande parte da população, que se encontra em meio a uma visível disparidade social.

É importante observar, como David Harvey explica, o problema dos trabalhadores no mercado: "a atual tendência dos mercados de trabalho é reduzir o número de trabalhadores 'centrais' e empregar cada vez mais uma força de trabalho que entra facilmente e é demitida sem custos quando as coisas ficam ruins" (Harvey, 1993, p. 144).

Harvey trata, no caso, do problema do enxugamento das empresas a que deu lugar o processo de reestruturação produtiva. Esse enxugamento é, como se sabe, provocado também pelo desenvolvimento tecnológico. Articulando de forma estreita a ciência e a tecnologia, essa fase de desenvolvimento do capitalismo ampliou o número de trabalhadores intelectuais em detrimento da mão de obra menos especializada.

A sua outra face é o trabalho flexível precarizado, que passa a engrossar as fileiras do trabalho informal que, segundo Harvey, é facilmente associável ao crescimento das "economias negras" subterrâneas, encontradas, inclusive, em "todo o mundo capitalista avançado" (Harvey, 1993, p. 145).

Essas formas de trabalho funcionam na sociedade como amortecedoras da crise, encobrindo a negligência dos Estados em relação à questão social, o que, de certa forma, legitima a flexibilização do trabalho e o desemprego.

É importante explicitar que o processo de reestruturação produtiva, ao incidir de forma tão contundente na divisão do trabalho, atinge tanto os 
trabalhadores centrais como os periféricos, deixando em uns e outros suas sequelas; nos primeiros, pelo aumento das responsabilidades e da carga excessiva de trabalho que invade inclusive a sua vida privada ou, como querem alguns, "o mundo da vida"; nos segundos, pela insegurança a que são jogados com a perda da estabilidade e dos direitos que os deixa sem presente e sem futuro, expostos aos "acessos da existência" (Santos, 1999).

Isso se dá tanto com os que perdem postos de trabalho como com aqueles que ainda não tiveram acesso ao mercado de trabalho. De qualquer forma, são os trabalhadores menos preparados para as mudanças tecnológicas que resistem nas filas dos postos de trabalho e/ou no mundo da informalidade, quer pela perda da identidade e dos vínculos construídos como trabalhador, quer pela destruição progressiva da esperança de se ver como tal.

Mas não é apenas o indivíduo enquanto tal que perde a identidade. São as organizações sindicais e outras associações que também se desestabilizam. Nas palavras de Antunes:

Com o aumento do abismo social, no interior da própria classe trabalhadora, reduz-se fortemente o poder sindical, historicamente vinculado aos trabalhadores "estáveis" e, até agora, incapaz de aglutinar os trabalhadores parciais, temporários, precários da economia informal etc. (Antunes, 2000, p.70).

Pondo o acento na divisão do trabalho que cria uma diferenciação na classe trabalhadora, Antunes observa os reflexos do problema nas organizações dos trabalhadores, como a tendência de diminuição das taxas de sindicalização verificadas por estudiosos. Quer dizer, o número de sindicalizados torna-se menor do que a população de assalariados na maioria dos países capitalistas industrializados. Paralelamente, encontra-se uma subproletarização do trabalho que se estende cada vez mais, na medida em que formas de trabalho precário, temporário e parcial são reunidas nesse processo.

O processo de qualificação do trabalho intelectualizado industrial desqualifica outros tipos de trabalho, causando, segundo Antunes (2000), uma fragmentação da classe trabalhadora que se torna heterogeneizada e mais complexa.

A intensificação da ciência enquanto força produtiva contribui para tal processo, tendo em vista que ela se torna responsável pelo surgimento de novos níveis de classe, como a classe dos trabalhadores intelectuais, assim 
denominado por estudiosos como Gorender (1999). Estes se encontram no setor de serviços, que se tornou cada vez mais ampliado e autônomo. O setor de serviços é, segundo Gorender, o grande responsável pela heterogeneidade da classe trabalhadora, já que provoca uma diferenciação entre o trabalho intelectual e o manual, produzindo disparidades em relação aos salários, e aos modos de vida dos trabalhadores.

Trabalhando em outro registro Dejours atribui também tais elementos a atual fragilidade da organização sindical, que fez vistas grossas à alienação provocada pelo trabalho. Para esse estudioso, "a questão da alienação repercutiu intensamente no mundo dos trabalhadores e dos empregados, mas foi quase sistematicamente descartada do debate pelas grandes organizações sindicais" (Dejours, 2001, p. 37).

Quer dizer, segundo Dejours, é o esquecimento do sofrimento no trabalho pelos sindicatos o principal responsável pelas dificuldades históricas e articulação dessas organizações que desembocam hoje no aumento da fragilidade da organização.

De qualquer modo, é importante sublinhar que esse sofrimento não advém apenas da insegurança e precariedade do trabalho. A este se alia também a perversidade das novas formas de gestão que pressionam os trabalhadores estáveis e não estáveis no sentido do cumprimento das metas e da imagem da empresa perante a sociedade. Conforme Dejours: "esses novos métodos se fazem acompanhar não apenas de demissões, mas também de uma brutalidade nas relações trabalhistas o que gera muito sofrimento" (Dejours, 2001, p. 23).

Seja como for e analisando a problemática atual de modo mais geral, o autor sublinha que não foi apenas “(...) a taxa de desemprego que mudou, e sim toda a sociedade que se transformou (...)" (Dejours, 2001, p. 23). Nesse sentido, ele sublinha que há, também, um processo de "(...) atenuação das relações de indignação, de cólera e de mobilização coletiva para a ação em prol da solidariedade e da justiça (...) (e inclusive) uma (...) franca indiferença bem como tolerância coletiva (...) ao sofrimento alheio" (Dejours, 2001, p. 23).

É como se o trabalhador, o empregado e o desempregado, ficasse preso a esse círculo vicioso em que perde força o coletivo e o individual. Preso nesse círculo, o trabalhador não reage aos novos métodos de gestão e direção que subtraem dele as conquistas históricas e o direito ao trabalho, e os sindicatos, 
por sua vez, perdem, cada vez mais a força de mobilização necessária à superação das condições perversas a que estão submetidos os trabalhadores na atual conjuntura.

No entanto, diante da investida neoliberal e das reformulações capitalistas no interior da produção, se torna cada vez mais latente a necessidade de luta pelo reconhecimento e afirmação dos direitos da classe trabalhadora. Ainda que seja, como aponta Guerra, "insuficiente, já que as próprias premissas de produção e reprodução ampliada do capital limitam o caráter de universalidade dos direitos sociais formalizados na Constituição Federal" (Guerra, 2010, p. 33).

Mesmo que não nos aprofundemos na questão dos direitos sociais, tendo em vista os objetivos deste estudo, vale aqui pontuar a incompatibilidade da ideologia capitalista com a garantia dos direitos sociais. Cada vez mais a intervenção do Estado fica limitada a atender as várias expressões da questão social, focalizando suas ações nos segmentos da população de maior risco social.

Considerando o foco de análise aqui adotado, o trabalho enquanto direito está longe de ser um direito fundamental protegido. Nasce, segundo alguns autores, na segunda geração ${ }^{3}$ dos direitos humanos e resulta do embate entre forças distintas da sociedade, primordialmente do modelo burguês de sociedade, onde o Estado liberal se consolida a partir do crescimento da economia industrial. Com base em Marques, "sabemos que é de vital importância que o homem possa trabalhar e de seu esforço retirar o sustento para si e seus dependentes, com mínimas condições de dignidade. Assim, tem o 'direito ao trabalho' emblemático e relevante significado" (Marques, 2010, p. 84).

O artigo 23 da Declaração Universal dos Direitos do Homem salienta que "todo homem tem direto ao trabalho, à livre escolha de emprego, a condições justas e favoráveis de trabalho e à proteção contra o desemprego" ". Essa premissa pode ser encontrada em diversas constituições, todas valorizando a liberdade de escolha.

Dessa forma, a constituição vigente no Brasil garante o direito ao trabalho como um direito social (Constituição Federal, 1988, art. 6º).

\footnotetext{
${ }^{3}$ Sobre a classificação dos direitos em "gerações", ver ABRAMOVICH e COURTIS (1997), que desenvolvem uma crítica interessante a esta classificação.

${ }^{4}$ Disponível em <http://www.dhnet.org.br/direitos/deconu/textos/integra.htm>. Acesso em 15 jul. 2013.
} 
Podemos considerar, então, que o direito ao trabalho significa, concordando com Marques (2010), o acesso à atividade produtiva remunerada, ou seja, ao emprego. Diferentemente do direito do trabalho, que inclui de forma complementar comportando, segundo a referida autora, "elementos de direito público e privado, ainda que de marcado assento contratual, como a disciplina que envolve a pessoa do trabalhador nas relações possíveis no mundo do trabalho" (Marques, 2010, p. 90).

Já o direito do trabalho se assenta nas questões contratuais entre patrões e empregados, de forma que vem se modificando de acordo com as restrições impostas pela necessidade do capital em se expandir. Por essa razão, o direito do trabalho torna-se cada vez mais vulnerável, ficando a mercê de contratos e "benefícios" cada vez mais empobrecidos e incapazes de oferecer à classe trabalhadora condições dignas de reprodução e sobrevivência.

Enquanto o direito ao trabalho significa a luta pelo acesso ao emprego, o direito do trabalho resiste às investidas da redução dele e de sua qualidade, forçando o aparecimento de um perfil diferenciado de trabalhador, mais eficiente, produtivo, que assume acúmulo de responsabilidades, agindo de forma autônoma no interior da empresa, convencido de que necessita unir-se ao empregador pela sobrevivência da empresa que, por sua vez, assume uma postura de coadjuvante da relação capital $x$ trabalho, transferindo para sua "clientela" a responsabilidade de manter os lucros e, assim, os salários de seus empregados.

Isso torna mais fácil manipular a massa de trabalhadores, que aceita tal subordinação e ainda colabora com a produção, zelando pelos resultados para manter o funcionamento da empresa, o que o afasta de seus pares na luta por melhores condições de trabalho, aceitando a redução de salários, proteção e benefícios, mascarando, assim, os conflitos de classe.

Contudo, houve tentativas para abrandar a situação do direito dos trabalhadores. A Organização Internacional do Trabalho (OIT) editou, na 95a Conferência Mundial, de 15 de junho de 2006, a Recomendação № 198, sobre a relação de trabalho ${ }^{5}$, onde elenca uma série de considerações ligadas ao trabalho decente, que trataremos a seguir.

\footnotetext{
${ }^{5}$ Texto disponível em <http://www.oit.org.br/>. Acesso em 07 out. 2012.
} 
Segundo a OIT existem leis de proteção, "existe proteção oferecida pelas leis e regulamentos nacionais e acordos coletivos" (Organização Internacional do Trabalho, 2006). E este é um dos aspectos centrais deste estudo. Tomando como exemplo o setor elétrico brasileiro que, dentro da sua nova estrutura, pode abrigar tais considerações, porém, com novas roupagens, que podem apontar para uma situação real bem diferente das recomendações da OIT. Neste sentido, a empresa $X$, também tem seu discurso comentado neste estudo, diante do exemplo que trazemos, quando buscamos indagá-la, por intermédio de alguns de seus gestores, sobre a efetivação de um trabalho decente, de fato e direito, no âmbito das novas formas de gestão por processos que vem adotando.

\section{3. Onde está o trabalho decente? Origem e conceitos}

Tomando como base o que preconiza a $\mathrm{OIT}^{6}$, o trabalho decente é o ponto de convergência dos quatro objetivos estratégicos da referida organização: o respeito aos direitos no trabalho (em especial aqueles definidos como fundamentais pela Declaração Relativa aos Direitos e Princípios Fundamentais no Trabalho e seu seguimento, adotada em 1998: (1) liberdade sindical e reconhecimento efetivo do direito de negociação coletiva; (2) eliminação de todas as formas de trabalho forçado; (3) abolição efetiva do trabalho infantil; (4) eliminação de todas as formas de discriminação em matéria de emprego e ocupação), além da "promoção do emprego produtivo e de qualidade, a extensão da proteção social e o fortalecimento do diálogo social" (Organizaçâo Internacional do Trabalho, 2006).

Além da promoção permanente das Normas Internacionais do Trabalho, do emprego, da melhoria das condições de trabalho e da ampliação da proteção social, a atuação da OIT, no Brasil, tem se caracterizado, no período recente, pelo apoio ao esforço nacional de promoção do trabalho decente em áreas importantes, como o combate ao trabalho forçado, ao trabalho infantil e ao tráfico de pessoas para fins de exploração sexual e comercial, à promoção da

\footnotetext{
${ }^{6}$ Informações disponíveis em: http://www.oitbrasil.org.br/content/o-que-e-trabalho-decente. Acesso em 07 de out. 2012.
} 
igualdade de oportunidades e tratamento de gênero e raça no trabalho e à promoção de trabalho decente para os jovens, entre outras.

Em maio de 2006, o Brasil lançou a Agenda Nacional de Trabalho Decente (ANTD), em atenção ao memorando de entendimento para a promoção de uma agenda de trabalho decente no país, assinado pelo então presidente da República, Luiz Inácio Lula da Silva (2003-2010), e pelo diretor-geral da OIT, em junho de 2003. A Agenda define três prioridades: a geração de mais e melhores empregos, com igualdade de oportunidades e de tratamento; a erradicação do trabalho escravo e eliminação do trabalho infantil, em especial em suas piores formas; e o fortalecimento dos atores tripartites e do diálogo social como um instrumento de governabilidade democrática. De acordo com o memorando, as organizações de empregadores e de trabalhadores devem ser consultadas permanentemente durante o processo de implementação da Agenda.

O Brasil é pioneiro no estabelecimento de agendas subnacionais de trabalho decente. O Estado da Bahia lançou sua agenda em dezembro de 2007 e o Estado de Mato Grosso realizou em abril de 2009 a sua Conferência Estadual pelo Trabalho Decente, com o mesmo objetivo.

O caminho que levou à convocação deste processo de consulta nacional teve seu início em junho de 2003, quando o diretor-geral da OIT e o presidente do Brasil assinaram um memorando de entendimento que previa o estabelecimento de um programa especial de cooperação técnica para a promoção de uma Agenda Nacional de Trabalho Decente (ANTD) no Brasil, em conjunto com as organizações de empregadores e de trabalhadores.

Entre 2003 e 2010, diversas instâncias consultivas e deliberativas sobre o tema foram constituídas, tendo sido construídos consensos no campo da promoção do trabalho decente no país ${ }^{7}$.

Em maio de 2006, a ANTD foi lançada em Brasília pelo Ministério do Trabalho e Emprego (MTE) por ocasião da XVI Reunião Regional Americana da OIT, durante a qual também foi lançada, pelo diretor-geral da OIT, a Agenda Hemisférica do Trabalho Decente (AHTD).

Com o objetivo de contribuir para a erradicação da pobreza e para a redução das desigualdades sociais, a ANTD se estrutura em torno de três

\footnotetext{
7 Como exemplo pode ser citada a iniciativa da Central Única dos Trabalhadores (CUT) em publicar a Cartilha do Trabalho Decente, em 2011.
} 
prioridades: (1) a geração de mais e melhores empregos, com igualdade de oportunidade e de tratamento; (2) a erradicação do trabalho escravo e do trabalho infantil, em especial, em suas piores formas; e, (3) o fortalecimento dos atores tripartites e do diálogo social como instrumento de governabilidade democrática. Elaborada por um grupo de trabalho interministerial coordenado pelo MTE, com assistência técnica permanente da OIT, e submetida à consulta no âmbito da Comissão Tripartite de Relações Internacionais (CTRI), a ANTD estabelece resultados esperados e linhas de ação para cada uma das prioridades definidas.

O processo de implementação da ANTD ganhou novo impulso no final de 2007, com a constituição de um Grupo Técnico Tripartite (GTT) de consulta e monitoramento. Também avançou, nesse período, a discussão sobre os indicadores para monitorar os avanços nas diversas dimensões do trabalho decente e na experiência pioneira de elaboração de agendas estaduais (Bahia, Mato Grosso) e intermunicipais (região do ABC Paulista) de trabalho decente.

O passo seguinte foi a elaboração do Plano Nacional de Emprego e Trabalho Decente (PNETD), a partir de uma proposta construída por um grupo interministerial mais amplo que o anterior, também coordenado pelo MTE e com a assistência técnica da OIT. No dia 4 de junho de 2009 foi formalizado, por Decreto Presidencial, o Comitê Executivo Interministerial encarregado da elaboração do PNETD, concebido como um instrumento de implementação da ANTD.

Durante o ano de 2009 o PNETD foi intensamente discutido por diversas áreas do Governo Federal e pelo Grupo de Trabalho Tripartite (GTT), em um processo de diálogo social. Como resultado, foi construído um consenso tripartite em torno às prioridades e resultados do PNETD, referendado por um documento firmado por representantes de governo, empregadores e trabalhadores durante a 98 $8^{\text {a }}$ reunião da Conferência Internacional do Trabalho (junho de 2009). Na ocasião, uma Declaração Conjunta assinada pelo Presidente Lula e pelo diretorgeral da OIT reafirmou o compromisso entre o governo brasileiro e a OIT, em relação ao tema.

Com base no que preconiza a OIT, o trabalho decente pode ser definido como um trabalho adequadamente remunerado, exercido em condições de liberdade, equidade e segurança, capaz de garantir uma vida digna aos trabalhadores. Trata-se de um conceito amplo, que busca abarcar todas as 
dimensões do trabalho e tem por objetivo o combate à precarização e à deterioração dos instrumentos de proteção e inclusão social, que vêm ocorrendo há cerca de três décadas em nível mundial e aprofundado no Brasil na década de1990, sob o ideário neoliberal.

Contudo, ainda que a intenção declarada pela OIT caminhe na direção da promoção do trabalho decente, onde o trabalhador receba um salário digno e garanta o atendimento às suas necessidades básicas, através do exercício pleno do direito ao trabalho e do trabalho, a realidade da estrutura e das relações entre capital e trabalho caminham em direções opostas.

Enquanto houver um mercado de trabalho como o constituído hoje, valorizando uma alta rotatividade de trabalhadores, não conseguiremos avançar de maneira efetiva na direção do trabalho decente na forma sugerida pela OIT. É importante que a discussão sobre o trabalho e emprego avance na direção do trabalho de qualidade, ou seja, que tipos de empregos são criados? Como eles estão distribuídos no mercado? Por que razão alguns empregos são melhores que outros, analisando o mercado em termos de diferenciação e igualdade?

Sem essas análises nos parece que não haverá avanços significativos para a promoção do trabalho decente, como desejado.

O trabalho precarizado tornou-se a principal característica do mercado cada dia mais competitivo, onde a produção de mais valia supera qualquer necessidade de estabelecer, em seu interior, condições justas e dignas de trabalho.

Parece haver uma preocupação para que o trabalho decente possa suprir condições contratuais e de trabalho, desconsiderando formas importantes ligadas às características próprias dos empregos como: natureza do trabalho, complexidade e qualificação.

Portanto, o trabalho decente não traz muita novidade no tocante ao que já vem se discutindo sobre a promoção de trabalho e luta contra o trabalho precário, discussão pautada desde os anos 70-80. É necessário observar que o trabalho decente acaba enfatizando um duelo entre o que é "decente" e o que é "precário", quando o mais significativo talvez seja conhecer o que diferencia os empregos e, consequentemente, atacar a raiz da questão. Segundo Mocelin (2011): 
Em termos analíticos, a perspectiva do trabalho decente, embora necessária ao contexto latino-americano, estaria definida por critérios insuficientes, pois nivelaria os empregos de forma rasteira, com pouca ou baixa qualidade. A própria concepção de "trabalho decente" nada mais é do que um contraponto direto à concepção de "trabalho precário". O parâmetro de análise seria o contraponto do trabalho precário, atacando, especialmente, a questão da informalidade, da "desproteção" social dos trabalhadores e da instabilidade no vínculo contratual, não contemplando a análise sobre a origem da qualidade do emprego e seus fatores determinantes (Mocelin, 2011, p. 61).

No Brasil, desde 1990, a discussão do trabalho precário vem se justificando através da situação do emprego, que apresentava características de precarização com a denominada reestruturação produtiva. A informalidade e a terceirização se colocaram como formas de emprego mais comuns no mundo do trabalho no Brasil, demonstrando que o foco de discussão precisa ser direcionado para essas novas características do emprego.

As indicações aqui pontuadas são importantes para entendermos a necessidade de mobilidade, não só do trabalhador enquanto classe ou indivíduo, mas do trabalho enquanto categoria, imposta pelo sistema capitalista ao longo de sua trajetória, em busca de novas formas de exploração, em prol de sua sobrevivência. Razão pela qual mereceram aprofundamento e tratamento mais detalhado no processo de pesquisa. 


\section{3 \\ O setor elétrico brasileiro e o mercado competitivo financeiro}

\section{1. \\ Breve história do setor elétrico brasileiro e sua entrada no mercado competitivo financeiro}

Desde o início da utilização da energia elétrica no Brasil, na virada do século XIX para o século XX, até o fim da Segunda Guerra Mundial, a exploração dos serviços de eletricidade no Brasil era um monopólio privado ${ }^{8}$. Com raras exceções, em escala muito pequena, todas as atividades do setor elétrico estavam a cargo de concessionárias privadas, na maioria estrangeiras ${ }^{9}$.

Essa situação subsistiu sem grandes problemas até o momento em que o Brasil deixou de ser um país essencialmente agrícola e de população predominantemente rural para guiar-se rumo à industrialização, numa mudança de curso que, por sua vez, gerou um acelerado processo de urbanização, com efeito, sensível na demanda de energia elétrica, tanto no setor industrial, como no consumo geral.

Isso, aliás, não ocorreu somente nas grandes cidades; ocorreu também nas pequenas vilas de interior afetadas pela migração das áreas rurais. Enquanto novos segmentos de expansão econômica surgiram, com exigências de energia elétrica abundante, as comunidades, em geral, onde quer que se

\footnotetext{
${ }^{8}$ A primeira unidade produtora de energia no país foi a Usina Termelétrica de Campos, RJ, instalada em 1883, inaugurando a prestação do serviço público de iluminação na América do Sul. A preferência pelo modelo hidrelétrico também é antiga. A primeira hidrelétrica brasileira também foi construída em 1883, em Diamantina, MG.

${ }^{9}$ Era muito difícil naquela época construir uma usina elétrica. O Brasil não tinha nenhuma fábrica de máquinas térmicas, nem possuía grandes reservas exploradoras de carvão ou petróleo, que são os combustíveis dessas máquinas). O panorama só começou a mudar realmente a partir da Primeira Guerra Mundial, pois ficou muito difícil importar e, por isso, muitos bens passaram a ser feitos aqui. Isso fez com que numerosas indústrias viessem para o Brasil, principalmente para São Paulo, todas elas precisando consumir grandes quantidades de energia elétrica. O governo resolveu então dar incentivos para as empresas de energia elétrica que quisessem vir para o Brasil. Em 11927 deu-se a criação da São Paulo Railway, Light and Power Empresa Cliente Ltd $S P$ Railway -, evidenciando a entrada do capital estrangeiro no setor elétrico. A mais importante foi a Band and Share, norte-americana que organizou, na época, dez empresas de energia elétrica, localizadas em nove capitais brasileiras e na cidade de Pelotas (RS). Fonte: A Eletrobrás e a história do setor de energia elétrica no Brasil. Rio de Janeiro: Centro da Memória da Eletricidade no Brasil, 1995.
} 
localizassem, já não aceitavam mais a privação de um serviço tão essencial ao seu bem-estar pessoal e econômico.

Ocorre que, naquela época, a par do tradicional desinteresse do capital privado por investimentos nos serviços de eletricidade de pequenas cidades e áreas rurais, as concessionárias estrangeiras detentoras da maior parte do mercado, por diferentes motivos, dentre os quais pesava bastante o regime tarifário da época, começavam a enfrentar dificuldades crescentes na captação de novos recursos financeiros para atender ao crescimento do consumo em suas próprias áreas de concessão, onde já não encontravam abrigo fácil - como até então acontecia - as indústrias de maior porte que nelas estivessem por fixar-se e que despontavam por toda parte em consequência do processo de industrialização do país.

Esses foram os primeiros passos para que o Estado fosse obrigado a investir em projetos de industrialização pesada, tendo como principal papel a afirmação do polo urbano industrial. Houve uma centralização e nacionalização dos instrumentos responsáveis pelo controle financeiro, neutralizando, assim, a ideologia regionalista da República Velha. Foram desenvolvidas, ainda, modelos de substituição de importações que garantiram o consumo interno e equilibraram os níveis de emprego no país, para manter o consumo e, consequentemente, a produção, já que não havia possibilidade de investimento com as importações devido a crise de 1929.

A estratégia dessas empresas era a concessão concentrada em centros urbanos potenciais de consumo, caso de São Paulo e Rio de Janeiro. A Light Serviços de Eletricidade S.A. (Light) diversificou suas atividades e entrou no mercado de transmissão. Entre 1915 e 1945 a Light, centrando seus serviços em uma área territorial reduzida, detinha mais de $40 \%$ da capacidade instalada brasileira. No campo regulamentar a Light buscou desde o princípio assegurar contratos de concessão de longo prazo, além de dotá-los com cláusulas que impunham nos serviços e produtos, oferecidos no território brasileiro, o preço internacional. Fato proporcionado pela "cláusula ouro"10. Na área de produção

\footnotetext{
${ }^{10}$ I. O contratante, por si, empresa ou sociedade legalmente organizada, terá o direito exclusivo, dentro do perímetro do Distrito Federal, e por espaço de quinze anos a contar de sete de junho de mil e novecentos, de fornecer a terceiros energia elétrica gerada por força hidráulica, a fim de ser aplicada como força motriz e a outros fins industriais, salvos os direitos de terceiros, inclusive os que referem a produção e distribuição de luz. II. Findo o prazo dos quinze anos especificados na cláusula acima, o Contratante, ou quem explorar este contrato, gozará, durante trinta e cinco anos, de simples licença, sem direito exclusivo ou privilégio, para o fornecimento de energia elétrica gerada por força hidráulica. Fonte: <http://legis.senado.gov.br>. Acesso em 15 jul. 2013.
} 
procurou levantar e garantir a exploração da energia elétrica por meio dos potenciais hidráulicos, vez que a energia elétrica de origem hidráulica tem seu custo de produção bem menor do que as de origem térmica, ou seja, procurando também, garantir a conquista da renda hidráulica.

Assegurou, assim, a exploração da concessão por 50 anos e dotava o contrato de cláusula que impunha nos serviços e produtos, oferecidos no território brasileiro, o preço internacional. Medida que instaurava a correção cambial mensal nas tarifas, caso ocorresse a variação do câmbio.

A prestação desse serviço no interior do país era precário e quem o prestava era o poder público municipal e iniciativas privadas locais. A American \& Foreign Power Company (Amforp) concentrou suas atividades no interior de São Paulo e na maioria das capitais de estados brasileiros não atendidas pela Light. A estratégia, naquela época, já era a de comprar ativos existentes.

A crise de 1929 atingiu em cheio o Brasil, que tinha, então, uma economia centrada na exportação de produtos primários. Este cenário colocou em crise a oligarquia agroexportadora, abalando as relações de poder interno. Havia um claro projeto getulista de desenvolvimento do capitalismo nacional ${ }^{11}$ que, por se colocar numa posição de restrição à exploração promovida pelo capital estrangeiro, incluía o questionamento à forma como as empresas estrangeiras atuavam na exploração dos serviços de energia elétrica.

Essa conjugação de fatos, que aos poucos foi se tornando do conhecimento público e do empresariado em geral, agravada pela evidência de que o capital privado, tradicionalmente concentrado no atendimento dos grandes centros urbanos, não poderia por si próprio romper esse nó do nosso desenvolvimento, levou à convicção generalizada de que, mais cedo ou mais tarde, o poder público teria que participar de alguma forma no desenvolvimento da energia elétrica do país.

A empresa $X$, aqui estudada, que atua no setor de geração e transmissão de energia desde o ano de 1957, surge com a necessidade de atender a uma demanda cada vez maior de consumo de energia. O então presidente da República, Juscelino Kubistchek ${ }^{12}$, com sua política baseada no Plano de Metas

11 Refiro-me ao o desenvolvimento econômico orientado pelo Estado nacional (nacionaldesenvolvimentismo), que foi um aspecto central da ideologia política de Getúlio Vargas.

${ }^{12}$ Seu mandato como presidente da República foi de 1956 a 1961. No período o Brasil viveu um período de notável desenvolvimento econômico e relativa estabilidade política. Juscelino Kubitschek empolgou o país com seu slogan "Cinquenta anos em cinco", conseguiu empreender 
que tinha como pilar investimentos em alguns setores chaves, como energia, transporte, indústria pesada e alimentação, criou, por escritura pública, a primeira empresa de energia do país, que estava ameaçado por um colapso no sistema energético. O Plano de Metas de Juscelino Kubistchek alavancou a produção industrial brasileira. Ele também se propunha a atingir grandes metas em outras áreas como educação, alimentação, transportes e energia.

Todas as grandes construções realizadas no governo Juscelino Kubitschek só foram possíveis com o uso do capital estrangeiro (como a construção de Brasília, a nova capital do Brasil, inaugurada em 21 abril de 1960). Tais investimentos aumentaram a dívida externa do país. A inflação cresceu como nunca havia acontecido.

No início da década de 1960, ainda no governo de JK, foi criado o Ministério das Minas e Energia, que incorporou o Conselho Nacional das Águas e Energia Elétrica ${ }^{13}$, tendo o Estado atividades produtiva, financeira e de planejamento no setor. Ao mesmo tempo, a nova política de governo oferecia ao mercado internacional investimentos que garantiam elevadas taxas de juros. As indústrias nacionais tiveram um salto na sua acumulação decorrente dos avanços tecnológicos e produtivos, principalmente no setor de bens duráveis. Ou seja:

Os efeitos de encadeamento da impetuosa instalação de setores de ponta na produção de bens de duráveis atingiram, igualmente, os investimentos estatais em infraestrutura alargando-os. [...] do ponto de vista quantitativo os resultados do plano de metas foram exitosos, por mais que, em seu conjunto, eles, representassem a desnacionalização da economia brasileira (Mendonça, 1998, p. 68).

Com o fim da era JK cumpre-se, parcialmente, o seu objetivo que era o de impulsionar a economia do país através da motivação à industrialização, não só na área de produção de bens duráveis, mas também na indústria

um processo de rápida industrialização, tendo como carro-chefe a indústria automobilística. Houve, no seu governo, um forte crescimento econômico, porém, houve também um significativo aumento da dívida pública interna e da dívida externa e da inflação nos governos seguintes de Jânio Quadros e João Goulart. Os anos de seu governo são lembrados como "Os Anos Dourados", coincidindo com a fase de prosperidade norte-americana conhecida como "The Great American Celebration", a qual se caracterizou pela baixa inflação e pelas elevadas taxas de crescimento da economia e do padrão de vida dos norte-americanos.

${ }^{13}$ Essa medida trazia radical mudança na regulamentação da exploração dos recursos naturais (hidráulicos e minerais), pois passavam a integrar os bens da União. 
automobilística, o que fazia do Brasil o "campeão mundial em energia elétrica" (Benjamim, 2001).

Assim, em 1961 o setor elétrico brasileiro apresentava um crescente desenvolvimento e aumento da potencialização de energia gerada, livrando o Brasil de um possível colapso energético e permitindo um crescimento urbano e industrial na região. Porém, é importante dizer que o desenvolvimento industrial veio acompanhado de índices crescentes de inflação e de politização, onde ganha expressão o desenvolvimento do populismo ${ }^{14}$.

Os anos que se seguem foram atravessados por um período de ditadura militar (1964-1985), marcado por muitas resistências e manifestações em prol da derrubada do $\mathrm{Al}-5^{15}$, que seguia firmemente prendendo e torturando indiscriminadamente. Porém, o Brasil seguia com um crescimento econômico que proporcionou a construção de obras "faraônicas" como a Transamazônica e a Hidrelétrica de Ilha Solteira.

De 1968 a 1974 o país passou pelo "milagre brasileiro", quando a economia cresceu consideravelmente, possibilitando investimentos no setor elétrico.

O final do período militar apresentava uma agenda de Estado que pleiteava a diminuição de gastos públicos, desestatização da economia e a ampliação da abertura política. Os governos militares foram pressionados por

\footnotetext{
${ }^{14} \mathrm{O}$ termo populismo é utilizado para designar um conjunto de práticas políticas que consiste no estabelecimento de uma relação direta entre as massas e o líder carismático, comumente sem a intermediação de partidos políticos. Assim, o "povo", como categoria abstrata, é colocado no centro da ação política, independentemente dos canais próprios da democracia representativa. Exemplos típicos são o populismo russo do final do século XIX, que visava transferir o poder político às comunas camponesas por meio de uma reforma agrária radical ("partilha negra"), e o populismo americano, que, na mesma época, propunha o incentivo à pequena agricultura através da prática de uma política monetária baseada na expansão da base monetária e do crédito (bimetalismo). Historicamente, no entanto, o termo populismo acabou por ser mais identificado com certos fenômenos políticos típicos da América Latina, principalmente a partir de 1930, estando associado à industrialização, à urbanização e à dissolução das estruturas políticas oligárquicas, que concentravam firmemente o poder político na mão de aristocracias rurais. Daí a gênese do populismo, no Brasil, estar ligada à Revolução de 1930, que derrubou a República Velha oligárquica, colocando no poder Getulio Vargas, que viria a ser a figura central da política brasileira até seu suicídio, em 1954 (BASTOS, 2006).

${ }^{15}$ Ato Institucional no 5 ou Al-5 foi o quinto de uma série de decretos emitidos pelo regime militar brasileiro nos anos seguintes ao Golpe militar de 1964 no Brasil. O Al-5 sobrepondo-se à Constituição de 24 de janeiro de 1967, bem como às constituições estaduais, dava poderes extraordinários ao presidente da República e suspendia várias garantias constitucionais. Redigido em 13 de dezembro de 1968, o ato veio em represália à decisão da Câmara dos Deputados, que se negara a conceder licença para que o deputado Márcio Moreira Alves fosse processado por um discurso onde questionava até quando o Exército abrigaria torturadores e pedindo ao povo brasileiro que boicotasse as festividades do dia 7 de setembro. Mas o decreto também vinha na esteira de ações e declarações pelas quais a classe política fortaleceu a chamada linha dura do regime militar. $\mathrm{O} A \mathrm{Al}-5$ foi $\mathrm{O}$ instrumento que deu ao regime poderes absolutos e cuja primeira consequência foi o fechamento do Congresso Nacional por quase um ano (GASPARI, 2002).
} 
uma articulação cada vez mais corajosa das forças oposicionistas da sociedade civil, que exigiam basicamente a volta ao Estado de direito, com a convocação de uma Assembleia Nacional Constituinte, anistia política e justiça social. período foi marcado por greves de trabalhadores que reivindicavam melhores condições de vida. O processo de anistia e a "abertura" foram aprovados como lei no início da década de 80 (Gaspari, 2002).

Após muitos embates políticos partidários entre situação e oposição, deuse início ao processo de redemocratização no país, com destaque aos movimentos sindicais, que ainda na década de 1980 realizaram a primeira Conferência Nacional das Classes Trabalhadoras (Conclat). Nesse sentido, observa-se que a luta sindical no Brasil contribuiu muito para os avanços na discussão da redemocratização, ainda que não fosse reconhecida oficialmente.

Com a desagregação do modelo econômico imposto pela ditadura, o país enfrentou com o governo de José Sarney (1985 a 1990) o desafio da inflação, que sugou os salários dos trabalhadores e impediu o crescimento econômico. Entra em ação nesse momento o Plano Cruzado, cujo propósito era “(...) canalizar recursos da esfera especulativa para a produtiva e iniciar um processo de redistribuição de renda" (Sader, 1991, p. 44). O que se viu, porém, foi uma falsa impressão de inflação controlada seguida de grandes benesses para 0 capital privado.

Nos anos 90 o neoliberalismo ${ }^{16}$ ganha o cenário econômico e político brasileiro, dando início, no governo Collor (15 de março de 1990 a 29 de setembro de 1992, com o impeachment do presidente), a um movimento de privatização e de desmonte do Estado, "revolucionando" a economia e aumentando a dívida social.

Findava-se aí a ideia de Estado empreendedor e centralizador de marca desenvolvimentista. Como sublinha Sallum Jr.: "[...] a transnacionalização do capitalismo e a democratização da sociedade foram, sob várias modalidades de manifestação, os processos mais abrangentes de superação do Estado desenvolvimentista" (Sallum Jr., 1999, p. 25).

\footnotetext{
${ }^{16}$ Os termos neoliberal ou neoliberalismo estão sendo usados em referência às tentativas de recuperação do liberalismo, cujas consequências podem ser resumidas à fragilização do Estado nacional (na medida em que o setor público represente limites à irrestrita integração dos países à lógica financeira e especulativa), e à destruição das mais variadas expressões dos movimentos populares de resistência política aos propósitos dos mercados e da economia desregulada.
} 
De qualquer forma, o reformismo neoliberal chega ao Brasil com o atraso de mais de uma década. Essa demora deveu-se, mesmo, ao movimento de democratização que, abalando a ditadura, abriu uma brecha no tempo, permitindo uma crítica contundente aos modelos de desenvolvimento, de caráter dependente que, aprisionando o país a uma dívida externa colossal, jogou na miséria a maioria de sua população. Sem conseguir atualizar aqui o modelo de acumulação de base keynesianista-fordista, que the serviria de espelho, o desenvolvimentismo esgotou-se com a crise do keynesianismo, sem, entretanto, ter-se beneficiado das suas "virtudes".

Sem entrar em maiores considerações sobre isso, é importante dizer que esse modelo deu as bases de expansão do capitalismo mundial por quase um século. Como bem sublinha Harvey.

\begin{abstract}
O período de expansão do capitalismo mundial, iniciado ainda no final do século XIX que se estendeu até finais dos anos sessenta deste século, com seu auge no período pós-guerra, foi marcado pela ascensão de um novo padrão de desenvolvimento. Baseado na produção e consumo de massa, o modelo de acumulação denominado fordista-keynesiano, conformou-se num conjunto de práticas de controle do trabalho, tecnologias, hábitos de consumo e configurações de poder político-econômico (Harvey,1993, p.119).
\end{abstract}

Este modelo, símbolo do processo de produção mais eficaz da história, é corroído em suas bases. No final dos anos 60 , quando a queda na taxa de lucros provocada pelo aumento no valor da força de trabalho revela a sua insuficiência para manter o nível de consumo, já que não havia escoamento da produção devido ao desemprego estrutural. A intensificação do capital especulativo que deu independência à esfera financeira e, por último, a crise do Welfare State tendo como consequência maior a crise fiscal do Estado, deu margem a afirmação do processo de terceirização, que começou a flexibilizar a produção.

Diante disso, o sistema capitalista se viu obrigado a dar respostas. Uma das saídas encontradas foi a reorganização do seu sistema ideológico e político de dominação. Conforme já indicado em capítulo anterior, surge, então, segundo (Harvey, 1993, p. 40), o modelo de "acumulação flexível", que acompanhado de intensificada terceirização e de modificações do aparato estatal, desregulamentou os direitos trabalhistas e exigiu da produção uma nova estrutura, baseada em novas tecnologias e regras na produção, como nos Controles de Qualidade Total (CQT). 
Ou seja, nas últimas décadas do século $X X$ ocorreram significativas mudanças no sistema produtivo e na estrutura da sociedade e economia capitalista. O modelo keynesiano e fordista passou a ser questionado pelo neoliberalismo. Desenvolveu-se o modelo de produção flexível e as relações de trabalho foram seriamente afetadas e modificadas. E tais alterações, ocorridas na relação entre capital e trabalho, revelaram-se através de uma mudança de correlação de forças nitidamente desfavorável aos trabalhadores, pois o término do século passado e início do novo milênio revelaram uma nova roupagem de dominação capitalista baseada na flexibilização, na produção e nas relações de trabalho e, consequentemente, também trouxe a precarização do trabalho, traduzida em novos cenários de desemprego estrutural, desregulamentação social e da legislação do trabalho, aumento do emprego temporário e terceirização. Por conseguinte, novas exigências de perfil e qualificação do trabalhador foram impostas, tornando o mundo do trabalho mais hostil às camadas exploradas.

Essa conjuntura internacional vem ao encontro, no Brasil, de um modelo de desenvolvimento em franco processo de degradação.

A crise do capitalismo, que nos países desenvolvidos se tornou um grande divisor de águas na política de produção e acumulação mundial, refletese no Brasil e nos remanescentes da herança do "nacional-desenvolvimentismo" que começam a se reorganizar. Assim, alguns empresários se dão conta de que o Estado não respondia mais as crises que vinham se configurando no país e que vão da economia à política, atingindo o social. Isso se deu, sobretudo em razão dos dois choques do petróleo - em 1973 e 1979 - que aumentaram sobremaneira o preço do barril, mantido a preços baixos desde o pós-guerra, gerando alta inflação e outras disfuncionalidades à economia.

Nessa época o país vive uma crise de recessão e a classe trabalhadora, atingida por baixos salários e pelo desemprego, aprofunda suas reivindicações por melhores condições de trabalho e de vida. A ela se juntam movimentos de bairro e o movimento de trabalhadores rurais, todos reivindicando em uníssono 0 pagamento da dívida social. Foi nesse momento que a sociedade começou a responder ao ataque neoliberal, organizando-se.

Portanto, o neoliberalismo, no Brasil, assim como nos países da América Latina, proporcionou uma descentralização do poder do Estado sob a égide dos mercados, promovendo privatizações, convertendo direitos em bens ou 
"serviços", adquiríveis segundo regras do mercado. Essa expansão dos mercados resultando na "mercantilização da vida social" teve como consequência notória um desequilíbrio entre mercado, Estado e sociedade.

Esses acontecimentos incidiram diretamente sobre o setor elétrico, uma vez que as empresas, de uma forma geral, começaram a se endividar, diante da diminuição do ritmo de investimentos na década de 1980, associado ao aumento no consumo de energia elétrica, acima da capacidade instalada, o que gerou, na década de 1990, modificações nas regras de funcionamento do setor. Na era Collor os investimentos na área começaram a cair, como reflexo do endividamento das empresas estatais, que teve seu nascedouro na política de contenção tarifária desenvolvida na década de 1970, para combater a inflação.

Na reestruturação do setor elétrico estava embutida a ideia neoliberal de privatização, que buscava os seguintes objetivos: (1) transferir, do Estado à iniciativa privada, o ônus dos investimentos necessários à expansão da oferta de energia; (2) assegurar a eficiência econômica do setor, de modo a garantir a modicidade tarifária, que é um suprimento confiável de eletricidade à população com o menor custo possível; (3) estimular a participação dos consumidores nos processos regulatórios; e (4) universalização do acesso à energia elétrica.

Tal ideia se consolidaria através da divisão do setor em geração, transmissão e distribuição, o que mais tarde facilitaria sua privatização completa, ainda que dificultada por restrições constitucionais, que impediam, até então, a privatização dos setores correspondentes aos serviços de monopólio natural do Estado, tais como o petrolífero, o de telecomunicações e energia elétrica.

A primeira proposta de privatização foi apresentada em 1992 por Collor. Essa perspectiva ganha suporte político mais sólido e impulso adicional com a estabilização monetária alcançada em 1994, com o Plano Real, no Governo Itamar Franco (de 29 de dezembro de 1992, com o impeachment do presidente Collor de Mello, até 1994). Essa política econômica previa a inclusão da Light ${ }^{17}$

\footnotetext{
17 A Light Serviços de Eletricidade S.A., ou simplesmente Light, é uma empresa privada de geração, comercialização e distribuição de energia elétrica localizada no estado brasileiro do Rio de Janeiro. A companhia é responsável pela distribuição de energia elétrica na cidade do Rio de Janeiro (seu maior polo consumidor), além de boa parte da Baixada Fluminense (exceto o município de Magé). A Light é uma das três distribuidoras de energia elétrica no estado do Rio de Janeiro, juntamente com a Ampla e com a Energisa Nova Friburgo. A companhia é controlada pela CEMIG, sua maior acionista. Em 1905, o Brasil ainda não era um país industrializado e a Light dava início à construção da então maior e mais moderna usina hidrelétrica do país, a Usina de Fontes, situada no município de Piraí, no estado do Rio de Janeiro. Nas décadas seguintes, conforme o Rio de Janeiro crescia, entraram em operação outras usinas: Ilha dos Pombos (1924), de Fontes Nova (1940), Santa Cecília (1952), Vigário (1952), Nilo Peçanha (1953) e Pereira
} 
no Programa Nacional de Desestatização (PND), que emblematizou a adoção da ideologia neoliberal no Brasil: "agora o empresariado combate o intervencionismo estatal, clama por desregulamentação, por uma melhor acolhida ao capital estrangeiro, por privatizações. Em suma, passa a ter uma orientação cada vez mais desestatizante e internacionalizante" (Sallum Jr., 1999, p. 26).

Eleito, Fernando Henrique Cardoso promovera as primeiras medidas de ajuste do Plano Real, em função dos saldos negativos da balança comercial e do receio de que o capital fugisse do país. Quer dizer, diante da ameaça de uma crise cambial que afetaria o plano de estabilização, o governo decidiu aumentar as taxas de juros e restabelecer alguma proteção tarifária para o setor de automóveis e de bens duráveis, recuando, provisoriamente na política de abertura comercial. Estas medidas, de alguma forma, impediram o crescimento da inflação.

Porém, 1996 anunciou um desgaste provocado pelas altas taxas de juros, o que prejudicou o crescimento da economia e aprofundou a dívida com o Fundo Monetário Internacional (FMI). Renasce, assim, nas palavras de Sallum Jr. (1999), o "liberal desenvolvimentismo":

O que importa é que a maioria dessas necessidades teve como fonte de inspiração aquilo que denominamos antes liberal-desenvolvimentismo. Nele, o velho desenvolvimentismo dos anos 50 e 60 renasce sob predomínio liberal (Sallum Jr., 1999, p. 34).

De qualquer forma, como destacam estudiosos dessa política, o resultado foi o não investimento do setor elétrico em questão. Durante 15 anos (de 1985 a

Passos (1962). No final da década de 1970, o contrato de concessão da Light com o governo federal, assinado no início do século e com validade de setenta anos seria encerrado, com a entrega dos ativos investidos pela empresa ao governo brasileiro. Porém em circunstâncias obscuras, principalmente no momento político vigente (regime militar), o então ministro das minas e energia, através da Eletrobrás, adquiriu o controle acionário da Light e estatizou-a. A compra da Light marcou a conclusão do processo de nacionalização do setor de energia elétrica, iniciado em 1961 com a aprovação da lei que criou a Eletrobrás, consagrando a adoção da solução estatizante para o setor. A Light virou uma empresa estatal federal voltada à holding estatal federal Eletrobrás, sendo uma das principais empresas estatais do estado, mantendo a responsabilidade pelo fornecimento de energia elétrica nas principais cidades da Região Metropolitana do Rio de Janeiro e do Vale do Paraíba Fluminense. A Light foi privatizada pelo programa federal de desestatização através de leilão na Bolsa de Valores do Rio de Janeiro, em 21 de maio de 1996, onde os compradores da empresa passaram a controlar cerca de $80 \%$ do seu capital. Para cumprimento da legislação vigente sobre o setor elétrico, em que as atividades de geração, transmissão e distribuição de energia elétrica precisam ser alocadas em empresas diferentes, foi efetuado o processo de desverticalização da Light em 2005, originando empresas que formam o Grupo Light. Atualmente, é administrada pela Companhia Energética de Minas Gerais (CEMIG). 
2001) o Brasil enfrentou a sua maior crise no sistema, que desembocou no chamado "apagão", em 2001, embora a ameaça da crise pairasse no ar desde 1995.

Assim, a privatização volta ao centro das discussões. Essa era uma tentativa de mostrar ao Brasil que essa empresa $\mathrm{X}$, do setor elétrico, começava a dar prejuízos para o governo, alegando falta de recursos para continuar investindo na expansão da geração e distribuição de energia. Esse era então o "álibi perfeito" para atrair o capital privado, seja ele interno ou internacional.

Em uma nova tentativa de privatizar a empresa $X$ surge o segundo "fantasma", a cisão, que foi discutida em 1999. Esta teve por objetivo desmembrar a empresa para facilitar sua privatização, dividindo-a em geração e transmissão, permanecendo esta última com o governo federal e, consequentemente, privatizando a outra.

Com isso, os trabalhadores, organizados pelo sindicato, entraram em greve em junho de 2001 para protestar contra essa decisão do governo em desmembrar a empresa e, ainda, reivindicar as perdas salariais referentes aos últimos três anos, prevendo um reajuste de 16,06\%, bem como um acréscimo de $R \$ 2,00$ no tíquete alimentação, que naquele ano era de $R \$ 15,00$. Outra pauta reivindicatória era a extensão dos direitos aos empregados contratados após 1996, período em que a empresa ficou estagnada sem realizar concursos e subcontratando mão de obra contratada por outras empresas, ou seja, por terceirização - processo que já dura 17 anos. Esses foram alguns pontos da pauta de discussão apresentada em mesa de negociação entre o CNE (Comando Nacional dos Eletricitários) e o grupo Eletrobrás em 25/06/2001. Porém, esta discussão foi infrutífera, já que o reajuste de 16,06\% ficou em 6\%, O não atendimento das reivindicações gerou muita insatisfação ao longo do governo Lula, o que acabou por fazer que nova greve fosse deflagrada em julho de 2012, e permanecendo por 30 dias, uma das mais longas greves já ocorridas na empresa $X$.

Não obstante a crise acima relatada, decorrente da cisão, o ano de 2001 foi de muitas premiações para esta empresa, que divulgou os resultados do Prêmio Qualidade do Governo Federal, onde os responsáveis pelo controle técnico da empresa receberam o troféu das mãos do então presidente da República Fernando Henrique Cardoso, em dezembro de 2001, na categoria empresas públicas e sociedades de economia mista. 
A equipe premiada adotou o sistema de garantia de qualidade em 1999, juntamente com a maioria das empresas nacionais, levando em consideração que esse sistema foi implementado no Brasil a partir da década de 1970, seguindo o modelo japonês, adotando como prática Círculos de Controle de Qualidade (CCQ), a forma mais adotada deste modelo.

Porém, não permaneceu por muito tempo, já que esbarrava na resistência de supervisores e diretores de empresas que se negaram a abrir mão de práticas centralizadoras, características dos modelos anteriores de produção. Somente na década de 1990 é que se perceberam modificações no comportamento da massa mais resistente de empregados da empresa $X$ em relação ao modelo de qualidade total, que se caracterizava por práticas de gestão e organização do trabalho, como já visto no capítulo anterior, o que exigia um manual-padrão para todas as empresas, determinado pelas Normas de Gestão da Qualidade e Garantia da Qualidade - Diretrizes para Seleção e Uso NB 9000/ ISO 9000/1/2/3/4/5, da Associação Brasileira de Normas Técnicas (ABNT), tendo como objetivo principal, definido pelo modelo japonês, a "produtividade, redução de custos, qualidade e racionalização da organização do trabalho" (Druck, 1998, p. 59).

Como resultado da adoção desses programas, podemos citar, entre outros, a redução de custos, a produtividade e a qualidade do trabalho. Estes são frutos de um trabalho de mobilização para a participação do empregado, a fim de garantir a permanência da empresa no mercado. São apresentadas normas técnicas a serem seguidas, associadas a uma campanha de "conscientização" que inclui uma série de documentos como cartazes e folders que incentivam a participação e responsabilidade de cada empregado em manter a empresa na competitividade, produzindo com qualidade em prol da "modernização" e atendimento de novas demandas.

Contudo, nota-se que o discurso da participação gira em torno da lógica da acumulação flexível - responsável por atender às demandas com maior rapidez, gerando lucro - já que os trabalhadores passam a responsabilizar-se pela meta a ser atingida em termos de produção, reforçando que os empregados acabam inseridos, segundo Antunes: 


\begin{abstract}
Em um processo de organização do trabalho fundado numa resposta imediata à demanda, numa organização flexível do trabalho, numa produção integrada e que supõe necessariamente 0 envolvimento do trabalho, acarretando 0 estranhamento do trabalhador, sua "alienação" do trabalho, que se torna menos despótico e mais manipulatório (Antunes, 1996, p. 81).
\end{abstract}

Esse sistema de "flexibilização do trabalho", como coloca Antunes (1996), oferece aos trabalhadores prêmios de qualidade e excelência, porém flexibiliza também seus direitos, favorecendo o surgimento do trabalho precário e terceirizado. Há, ainda, uma despreocupação das empresas em adotar sistemas de "qualidade total" para as condições de trabalho, embora estejam incluídos no modelo japonês, como aponta (Druck, 1998, p. 60), a "gestão participativa, envolvimento dos trabalhadores e melhores condições de vida e trabalho, aspectos centrais da cultura da qualidade".

Conforme já indicado, tomamos como referência para este estudo o setor elétrico brasileiro, representado por uma de suas empresas. Pois bem, este é um exemplo de instituição onde, após inúmeros movimentos contra a sua privatização, sindicalistas e representantes do governo conseguiram, durante dois anos (1999-2000), embargar o processo, retirando esta empresa e todo o setor elétrico do Plano Nacional de Desestatização (PND).

Já no governo Lula (2003-2010), em uma das suas primeiras medidas, após desafogar o setor elétrico, começaram então novos investimentos para o setor através do Programa de Aceleração do Crescimento - PAC que, lançado em 28 de janeiro de 2007, é um programa do governo federal que engloba um conjunto de políticas econômicas, e que tem como objetivo acelerar o crescimento econômico do Brasil.

A partir de 2008 o governo federal intensificou os investimentos no setor elétrico, criando grupos de estudos determinado pelo Conselho Nacional de Minas e Energia - CNPE, para elaborar planejamento na área de geração e transmissão depreciadas ou amortizadas. Esta decisão do então ministro de Minas e Energia, Edson Lobão, está relacionada ao vencimento das concessões para a prestação de serviços de geração, transmissão e distribuição de energia elétrica, previsto para 2015.

Em setembro de 2012 foi apresentada uma proposta à presidenta da República Dilma Rousseff (2011-atual) pelo atual ministro Edson Lobão, que visa aperfeiçoar o setor elétrico, pela Medida Provisória (MP) 579/2012, e aprimora o 
marco institucional do setor, estabelecido em 2004, que tem como base dar tratamento específico para parte da energia elétrica, considerada obsoleta, produzida por usinas que tiveram grande parte de seus ativos depreciados ou amortizados. A MP 579/2012 prevê as prorrogações das concessões, por até 30 (trinta) anos, de empresas hidrelétricas que tiveram suas concessões antes de 1995, através da Lei no $9074^{18}$.

Com a renovação das concessões, as empresas produtoras de energia elétrica necessitarão se modernizar e tomar medidas que as coloquem em condições de competitividade. Para tanto, a empresa $X$ lançou, em setembro de 2012, seu projeto de reestruturação organizacional, com vistas a mudar seu organograma para a adoção de um modelo de gestão com foco em resultados, reforçando a lógica financeira da orientação por processos, de definir ganhos num espaço curto de tempo e utilizando o mínimo de recursos.

Para o governo Federal, esta medida, que desenhará novos critérios, proporcionará ao consumidor uma redução de $7 \%$ na conta de luz devido a diminuição das tarifas a partir de 2013, o que foi permitido pela seguinte razão, nas palavras do ministério responsável: "a estabilidade econômica e de equilíbrio fiscal consolidadas no Brasil permitiram ao governo criar agora as bases de um novo modelo de desenvolvimento, pautado pelo aumento da competitividade e da produtividade e pela distribuição de renda" (Brasil, 2012, p. 1).

Diante das modificações implementadas, parece clara a nova característica "empreendedora" da empresa X, com destaque para o objeto de estudo aqui apresentado, a gestão por processos, apresentada em setembro de 2012 para todos os empregados, que vem promovendo uma reestruturação organizacional com vistas a atender não só ao mercado, mas, também, as novas exigências do governo federal através do PAC - Plano de Aceleração do Crescimento.

Eis a razão para pesquisar sobre o setor elétrico brasileiro, representado nesta proposta de estudo pela empresa $\mathrm{X}$, detentora de $10 \%$ de toda a geração de energia elétrica do país, com uma potência nominal de 10.050MW, sendo $7.971 \mathrm{MW}$ instalados em usinas próprias e $2.079 \mathrm{MW}$ em parceria com a iniciativa

\footnotetext{
${ }^{18}$ Estabelece normas para outorga e prorrogações das concessões e permissões de serviços públicos e dá outras providências.
} 
privada ou em Sociedade de Propósito Específico $(\mathrm{SPE})^{19}$, garante o fornecimento de energia em uma área onde estão situados $63 \%$ dos domicílios brasileiros, que responde por $81 \%$ do Produto Interno Bruto (PIB) nacional.

Dessa forma, deste ponto em diante, para efeitos deste estudo, a empresa $X$ passa a ser o nosso foco de análise, considerando principalmente seu novo potencial reestruturado para atender as exigências do mercado financeiro e de produção de energia elétrica, setor no qual a empresa em questão já não é mais "soberana" desde a década de19 90, quando deu início a um novo padrão de concorrência, que tratava da transição de um modelo estatal para a participação mista, visando interesses neoliberais de privatização que permanecem até hoje incentivando a competitividade.

\section{2. \\ A necessidade de reestruturar para se manter produtiva: sobre a gestão por processos na empresa $X$}

No início de 2011 a empresa $X$ estava inserida num mercado que the demandava o enfrentamento de diversos desafios para o cumprimento de sua missão: garantir a confiabilidade do sistema e atender ao incremento da demanda, participando dos empreendimentos do Plano Decenal de Expansão de Energia (PDE 2019) ${ }^{20}$.

Isso significa algo novo para esta empresa, que até então seguia soberana na administração e nas construções das usinas geradoras de energia do país, e agora se torna mais uma no mercado financeiro e competitivo a participar de novas concessões e de demonstrar capacidade para renová-las. A atual concessão tem vencimento em 2015, o que trará impactos significativos em sua receita, já comprometida por uma série de motivos. De acordo com o plano de reestruturação da empresa $X$ :

\footnotetext{
19 É uma sociedade empresária, cuja atividade é bastante restrita, podendo, em alguns, casos ter prazo de existência determinado, normalmente utilizada para isolar o risco financeiro da atividade desenvolvida.

${ }^{20}$ Plano como instrumento de planejamento para o setor energético nacional, contribuindo para o delineamento das estratégias de desenvolvimento do país a serem traçadas pelo governo federal.
} 


\begin{abstract}
A necessidade premente de uma política de transparência, a falta de experiência na gestão e na Governança de Sociedade de Propósito Específico criadas em operação, a urgência na recuperação do clima organizacional desgastado e no equacionamento de pendências envolvendo grande parcela da força de trabalho (contratados, terceirizados e absorvidos) eram algumas das situações que clamavam por solução. Somam-se a elas o peso de uma estrutura de custos acima da média nacional e o necessário "enxugamento" da estrutura organizacional (Plano de Reestruturação da Empresa X, p. 7).
\end{abstract}

$\mathrm{Na}$ empresa $X$, os departamentos, que tinham como principal característica física a divisão em salas, passaram a receber apenas estações de trabalho ${ }^{21}$, compartilhando o mesmo espaço, o que, na lógica da administração, representa a busca do sincronismo organizacional, que é o alinhamento entre processos, estratégia da empresa e seu pessoal. Outra mudança está na inserção de dados concretos da realidade vivida pela empresa na simulação experimental da ferramenta. Isso significa que o desempenho do processo pode apontar para reduções de custos e tempo, o que pode alterar os resultados desejados.

A implementação da gestão por processos significa a possibilidade de tornar a empresa $X$ mais competitiva no mercado, através da otimização de custos e consequente aumento da eficiência na produção de energia elétrica.

Segundo o presidente da empresa $X$ : "nossa nova missão é nos tornarmos empreendedores, alinhando nossas práticas às práticas do mercado, tornando a holding mais orientada, eficiente e ágil”22. Essa medida foi criada para continuar no mercado após 2015, quando do final da concessão de geração, transmissão e distribuição de energia elétrica.

Diante das informações acima transcritas, buscamos questionar com este estudo, tendo em vista que o sistema capitalista se reinventa a todo o momento para responder as suas crises, se não seria a gestão por projetos ou processos, na ordem da organização do trabalho, mais um instrumento de exploração da força de trabalho em prol da acumulação de capital?

Tomando em conta que o fluxo de tais sistemas administrativos obedece a uma lógica cada vez mais competitiva e flexibilizada, a empresa $\mathrm{X}$ exige do trabalhador adaptar-se cada vez mais às novas formas de gerir serviços e produtos? E, por fim, o que as novas formas de gestão do trabalho reservam

\footnotetext{
${ }^{21}$ Espaços otimizados, onde ficam alocados vários trabalhadores no mesmo espaço, dividindo uma mesma rede de informações, em seus computadores.

22 Informação obtida em conversa com o presidente da Eletrobrás, como forma de aproximação do campo empírico de estudo, em setembro de 2012.
} 
para aquele que vive dele? Mais trabalho? Ou uma possibilidade de trabalho decente?

Segundo Harvey, "da mesma forma que o neoliberalismo surgiu como uma resposta à crise dos anos 70 , o caminho a ser escolhido hoje definirá o caráter da próxima evolução do capitalismo" (Harvey, 2010, p. 16).

É importante ressaltar que cabe aqui um debate entre a gestão por processos e a gestão participativa, para que fique claro até onde esta nova modalidade de gestão empresarial influencia nas relações de trabalho e na fragilização das mesmas, uma vez que o trabalho decente também transita nesse espaço. Neste sentido, há uma pergunta que procuramos responder: a gestão por processos abre possibilidades de ser também participativa?

A flexibilização tornou-se a palavra de ordem do "novo" capitalismo, como vimos anteriormente. Em todas as suas formas de organização prevalecem comportamentos individuais como valorosos, capazes de gerar competência, uma vez que este indivíduo precisa estar em todas as frentes e pronto para responder a qualquer "nó interligado à rede" que, em nossa discussão, pode ser considerada uma rede de comunicação entre pessoas.

Realizando uma crítica às hierarquias próprias de modelos mais antigos, Rosenfield afirma que "na atual fase do capitalismo dominam as empresas divididas em unidades autônomas, organizadas por projetos, com forte redução dos níveis hierárquicos" (Rosenfield, 2006, p. 247).

Diante disso, é possível inferir que a gestão orientada por processos é um novo modelo de organização adotado pelas empresas modernas e tem como principal estratégia ações horizontais que, segundo especialistas, são sistemas horizontais que não apenas melhoram a velocidade de resposta ao mercado e a capacidade da empresa em prover produtos de massa personalizados, mas, também aumentam a eficiência e eficácia dos macroprocessos (Rocha, 2004).

A gestão por processos tem ainda como premissa, entre outras, velocidade, flexibilidade, fazer mais com menos focando nas necessidades das funções e otimizando todo o processo. Para a administração, a organização vertical tal como é vista hoje faz com que cada um tenha uma visão pessoal do processo. Para Vasapollo: 
Para que o sistema seja sempre mais eficaz, as empresas se organizam com técnicas e tecnologia novas que aumentam o ciclo produtivo descentralizado, respondendo rapidamente às oscilações da demanda e às solicitudes dos clientes-consumidores (Vasapollo, 2005, p. 372).

É desta forma que a gestão por processos vê a sua relação com os clientes, sempre participativos no processo, pois assim consegue saber exatamente o que eles demandam, diminuindo custos e simplificando a produção ou serviços.

Em outras palavras, uma organização voltada para processos busca ampliar o horizonte de visão dos atores sociais que a compõem proporcionando-lhes enxergar por meio de um novo viés, com foco abrangente, não apenas parte do processo, e sim, o todo. A importância dos processos de trabalho aumenta na medida em que as empresas ficam com o conteúdo cada vez mais intelectual afastando-se do modelo fabril (Gonçalves, 1992, p. 32).

Outra característica desta forma de gestão refere-se à mudança de cultura e paradigma, como por exemplo: função $x$ processos; rigidez $\mathrm{x}$ versatilidade; departamento $x$ células de competências; chefe $x$ facilitador; desempenho da pessoa $x$ desempenho do processo, entre outros. A mudança de cultura que transforma departamentos em células de competências pode ser considerada a mudança mais visível e sensível para a organização como um todo, tendo em vista a alteração dos espaços de trabalho que esta gestão propõe. 


\section{A representação da nova gestão na relação capital trabalho: a pesquisa de campo}

Para desenvolver esta dissertação foi utilizada a pesquisa qualitativa, por ser adequada às questões levantadas por este estudo. De acordo com Mayring (2002), analisar um conteúdo de forma qualitativa permite considerar o sujeito em sua totalidade, assim como sua historicidade, interpretando a realidade estudada, guiada pelas referências teóricas tomadas como ponto de partida do estudo.

Esta abordagem foi considerada mais apropriada devido aos diversos fatores que envolveram o estudo como, por exemplo, a história da empresa estudada, que sofreu profundas modificações ao longo de sua existência, bem como suas consequências na modificação do trabalho e sua relação com o capital, neste universo do setor elétrico brasileiro, através da nova gestão orientada por processos, como vimos buscando demonstrar.

Como sujeitos participantes da pesquisa foram selecionados trabalhadores diversos da empresa, desde seu quadro gerencial, passando por empregados contratados e efetivos, atores constitutivos da relação capital $X$ trabalho, ou seja, sindicato, relações sociais e a direção da empresa. Foram entrevistados 10 trabalhadores no total.

Esta pesquisa teve como principal objetivo buscar junto a estes representantes diversos o panorama da relação capital $X$ trabalho no contexto da reestruturação que a empresa vem sofrendo, para então saber até aonde o quadro de trabalhadores foi afetado e como foi afetado ao longo do processo de implantação da nova estrutura da empresa. Com a nova estrutura e forma de gestão a empresa $X$ promove o trabalho decente? Ou o trabalho está ainda mais precarizado?

A metodologia adotada respeitou o posicionamento de cada empregado desta empresa e seu nível de envolvimento e conhecimento das modificações que a mesma vem sofrendo no seu processo de gestão. Dentre os 10 entrevistados havia 1 gerente de relações sindicais, 2 sindicalistas, 6 
empregados ( 3 efetivos e 3 contratados) envolvidos no processo desde o início e 1 gerente responsável pela implementação do processo de gestão.

A forma de condução das entrevistas tomou como base a técnica de levantamento trabalhada por Mayring (2002), onde a entrevista está centrada no problema.

As entrevistas foram semiestruturadas, ou seja, utilizou um roteiro préelaborado ${ }^{23}$, respeitando o roteiro proposto, relacionado de forma direta com o tema da pesquisa, buscando compreender os fenômenos da realidade na sua totalidade.

A documentação utilizada refere-se ao material histórico pertencente ao acervo documental e bibliográfico da própria empresa, assim como os documentos oficiais que descreveram os passos da implementação da gestão por processos na empresa X. Foram examinados, ainda, os boletins informativos do sindicato, material de grande importância para análise das discussões do acordo coletivo, estudado no sentido de avaliar se já existem consequências da implementação da nova gestão ou, ainda, se já existem sinais de mudanças futuras considerando as rodadas de discussões entre a empresa $X$ e seus trabalhadores, representados aqui pelo sindicato.

A análise dos dados se deu com base nos autores, conceitos e categorias estudados, o que significa, segundo Leandro (2005), ao referenciar Mayring (2002):

[...] analisar os textos de maneira sistemática por meio de categorias desenvolvidas a partir do material levantado e com base na teoria estudada. Sempre que surge um novo segmento que não se enquadra em nenhuma categoria existente, deve-se criar uma nova categoria. O resultado desta análise é um conjunto de categorias que são interpretadas de acordo com as questões da pesquisa (Leandro, 2005, p. 25).

Como visto acima, as categorias analíticas foram elaboradas neste trabalho de acordo com categorias teóricas previamente determinadas, como, por exemplo: a gestão por processos, o mercado, o trabalho e, por fim, o trabalhador, apresentadas nos itens subsequentes.

\footnotetext{
${ }^{23}$ Roteiro de entrevista disponível no anexo 3.
} 
Além disso, e para garantir os aspectos éticos da pesquisa, os entrevistados receberam e assinaram junto com a pesquisa o Termo de Consentimento Livre e Esclarecido (TCLE), disponível no anexo 4.

\section{1. \\ As modificações geradas na empresa $X$ a partir das exigências do mercado}

De uma maneira geral, percebe-se que a gestão por processos é vista pelos entrevistados como uma modificação necessária para a evolução da empresa. Entendendo que esta evolução está intimamente ligada às exigências do mercado de energia elétrica, que, como já mencionado aqui, atribui novas exigências à empresa $X$, tornando-a, consequentemente, mais competitiva.

Ainda que estes empregados tenham dúvidas sobre esse modelo de gestão, acreditam que ela irá atender de forma eficaz às necessidades da empresa $\mathrm{X}$ em relação aos resultados, à redução de custos, objetividade das tarefas e a qualidade na gestão. Parecem estar convencidos que a gestão por processos possibilita dar mais clareza às funções que cada um precisa desempenhar.

Um dos empregados entrevistados aponta para uma autonomia do sistema, limitando a ação do empregado sobre o processo. Segundo ele:

\footnotetext{
O sistema é autônomo e na verdade você depende dos outros sempre, para fazer alguma coisa, ou para aprovar ou desaprovar. Você tem limites cada vez mais restritos (Pesquisa de campo, entrevista com trabalhador contratado 1, setor de compras e licitação).
}

A declaração acima expõe uma empresa que está se adequando a este novo modelo de gestão, onde a falta de autonomia dos trabalhadores é uma das características mais visíveis, colocando o processo em primeiro lugar. No caso citado acima, se trata de um trabalho totalmente voltado para um sistema que envolve pagamentos a fornecedores, que tem seu processo ainda mais automatizado para atender as novas regras de pagamento da empresa. 
Interessante analisar a fala de dois sindicalistas que apontam para a diluição dos departamentos, valorizando a organização dos processos. Segundo um deles: "quando você fala o processo, não interessa mais em qual órgão você esteja o que interessa é o processo" (Pesquisa de campo, entrevista com sindicalista A).

Contudo, vale ressaltar que esta fala, aparentemente crítica, apresenta uma conformidade em relação às mudanças, pois o sindicalista destaca ainda que: "O ser humano tem essa capacidade de se adaptar às mudanças, ele tem uma certa resistência mas depois ele acaba se adaptando" (Idem).

Com uma fala mais crítica, porém acreditando na nova gestão, o outro sindicalista entrevistado aponta para uma falsa diminuição de custos, tendo em vista que os cargos de gerência extintos ainda conservaram suas gratificações por mais 24 meses, e os novos cargos, ao mesmo tempo, tomaram posse com suas novas gratificações. Ele informa:

\footnotetext{
$\mathrm{Na}$ realidade aumentaram o cargo de gerente. Quando eu tiro um gerente e transfiro para ele um colchão de 24 meses, esse cara na minha visão tá pra se aposentar. Fico me perguntando que economia é essa? (Pesquisa de campo, entrevista com sindicalista B).
}

A visão dos entrevistados é unânime quanto ao corte de custos que a empresa necessitará realizar para que a gestão por processos seja bem sucedida, começando pelo corte de pessoal, anunciado desde 2012 pela empresa $\mathrm{X}$, incentivado por planos de aposentadoria criados para tornar 0 desligamento da empresa mais atrativo para aqueles que já estão aposentados pela Previdência Social.

Porém, não só os aposentados estão convidados a se desligarem da empresa, os contratados também têm seu plano de incentivo para o desligamento, ou mais do que isso, um acordo com o Tribunal de contas da União (TCU), onde a empresa $X$ programa este desligamento até 2018, pode ser incentivado ou não.

Para os sindicalistas, no entanto, a privatização é clara, e hoje está sendo implantada de forma silenciosa, começando pelos enxugamentos. 
Porém, não só os recursos humanos serão reduzidos, os recursos financeiros também. Segundo o gerente responsável pela implementação da nova gestão orientada por processos, reestruturar com esta visão significa:

Ajustar o modelo funcional à necessidade de orientação por processos para se alcançar resultados melhores com menos recursos. Com o projeto de reestruturação da empresa, espera-se obter reduções de custos da ordem de $30 \%$ a $40 \%$, mantendo-se a qualidade dos serviços oferecidos atualmente (Pesquisa de campo, entrevista com gerente $\mathrm{Y}$, responsável pela implementação da nova gestão por processos).

O novo organograma, disponível no anexo 1, mostra a realocação e diminuição do número de superintendências, extinção de departamentos, substituídos por gerências, e fusão de divisões para reduzir seu número. Ou seja, esse quadro justifica a necessidade de enxugamento, uma vez que seu organograma foi reduzido, "otimizando" os processos.

O gerente entrevistado acredita que as mudanças patrocinadas pela gestão por processos ocorrerão em médio prazo. Para que isso ocorra será necessário que as pessoas recebam treinamento adequado para se enquadrarem no processo.

Outro item importante diz respeito às relações políticas, cultura forte na empresa $X$, relacionada aos cargos políticos que não fizeram carreira na empresa, além da questão da administração pública, que acredita ser um entrave devido a sua falta de agilidade, diferente da empresa privada. Segundo o depoimento de um empregado:

A empresa $X$ é uma empresa com uma cultura ainda muito movida pela prática política, o que a afasta em certas circunstâncias, do mercado competitivo (Pesquisa de campo, entrevista com trabalhador efetivo 2, setor de compras).

Quando perguntado sobre este mesmo ponto, a fala do sindicalista A concorda com a deste empregado, acrescentando que:

Ela [a empresa $\mathrm{X}$ ] para se adequar a uma empresa competitiva, ela tem que se livrar de amarras, e a meu ver, a interferência política do governo, porque o dono de uma empresa estatal, a meu ver, é o governo. O governo não dá liberdade para que estas empresas possam atuar no mercado, é simples (Pesquisa de campo, entrevista com sindicalista A). 
Estas duas falas estão ainda relacionadas à decisão do governo federal, através do Ministério de Minas e Energia, em reduzir a tarifa de energia elétrica para o mercado consumidor. Segundo o sindicalista A:

\begin{abstract}
Essa medida que se transformou em lei onde a intenção era reduzir a tarifa par ao consumidor final, usuários, na verdade não aconteceu por que só aconteceu para os consumidores de eletro intensivos, eu trabalho numa empresa de energia elétrica onde o consumidor final de área residencial, não conseguiu uma redução efetiva em sua conta de luz (Pesquisa de campo, entrevista com sindicalista A).
\end{abstract}

A questão política permanece na discussão ao entrevistar um empregado que acrescenta que esta é uma tentativa de privatizar, acreditando que é uma "ideologia de governo", onde o Estado não tem competência para administrar uma empresa que compete no mercado com outras empresas privadas. Segundo ele: "Isso que eles estão dizendo: se eu não tenho competência para fazer isso, eu passo para a iniciativa privada". Afirmando, ainda, que "a gestão por processos parte de um interesse político de enxugamento para privatizar e que não há interesse no progresso da empresa" competitivo (Pesquisa de campo, entrevista com trabalhador efetivo 2, setor de compras).

Por fim, de uma maneira geral a gestão por processos parece ser para todos uma necessidade. Possibilitará introduzir a empresa de forma competente no mercado competitivo, ainda que, para tanto, seja necessário que haja corte de pessoal e benefícios, o que analisaremos mais adiante.

\title{
4.2. \\ A concepção da gestão por processos pelo olhar dos entrevistados
}

Considerando que a necessidade de reestruturação da empresa $X$ partiu das exigências do mercado competitivo, espaço pelo qual a empresa passa a se integrar na busca por novas concessões na construção de usinas, buscou-se entender quais eram as principais necessidades e dificuldades enfrentadas por ela que desembocaram na decisão pela implantação da gestão por processos. 
Os entrevistados acreditam que existiam na empresa muitos departamentos executando funções semelhantes, sendo este um problema, considerando as metas de produção do mercado, necessitando estabelecer uma nova cultura, com o seguinte foco:

Formalização de processos, gerências competentes e não indicadas por amizade, escolha de projetos com foco real de interesse para a empresa e seu negócio competitivo (Pesquisa de campo, entrevista com trabalhador efetivo 3 , setor de transporte).

Para avançar na reflexão sobre esta cultura, conversei com outro empregado que apontou para a importância da integração dos dados na tomada de decisões. O que não ocorria antes da gestão por processos, segundo ele. No novo modelo, a empresa $X$ passou a redefinir atribuições e responsabilidades nos diversos níveis hierárquicos. Para isso haverá necessidade de realocar pessoal e enxugar a estrutura organizacional. Neste sentido, afirma, "os profissionais com atividades mais claras se comprometem mais" competitivo (Pesquisa de campo, entrevista com trabalhador contratado 4, setor de análise de sistemas).

O comentário acima exprime uma condição clássica de concordância da massa de trabalhadores com a nova gestão. Acreditam que a gestão por processos proporcionará maior integração entre as atividades desenvolvidas pelos trabalhadores, tornando-as mais "claras". Contudo, percebe-se com isso uma dinâmica que envolve o trabalhador em operações ligadas em rede e que estabelece um controle maior e uma falsa autonomia e "clareza", uma vez que só executam o que o processo exige, ficando alienados no interior da produção.

Continuando o processo de investigação, abordei outro empregado, um sindicalista que vê as modificações como algo "nebuloso", onde não se identifica "quem está com a caneta". Com isso ele se referia a tomada de decisões para por na mesa de negociação em relação ao acordo coletivo de trabalho, o qual estava em discussão por ocasião da entrevista (realizada em julho de 2013), e que está gerando uma greve por tempo indeterminado, tema ao qual voltaremos mais adiante.

Uma questão que merece ser aprofundada, em se tratando de adaptações da empresa $X$, é que se percebe, de uma maneira geral, entre os entrevistados, que a gestão, por um lado é necessária para uma reestruturação 
que deixará a empresa mais modernizada e ágil. Neste sentido, comparam a estrutura que está se desenhando à estrutura anterior, ajustada ao cenário antigo. Ouvido o gerente entrevistado, ele revela sobre o assunto:

A estrutura funcional anterior estava bem ajustada ao cenário antigo, de concessões e mercado garantidos. A partir do novo modelo regulatório de energia, aquela estrutura mostrou-se incompatível com as novas necessidades de agilidade e flexibilidade, com qualidade, que o modelo de gestão orientado por processos permite (Pesquisa de campo, entrevista com gerente $\mathrm{Y}$, responsável pela implementação da nova gestão por processos).

Diante do comentário acima, se faz necessária uma análise do organograma da empresa $X$ para melhor entendimento da fala deste entrevistado. O novo organograma (disponível no anexo 2) mostra a realocação e diminuição do número de superintendências, extinção de departamentos, substituídos por gerências, e fusão de divisões para reduzir seu número. Ou seja, esse quadro justifica a necessidade de enxugamento, uma vez que seu organograma foi reduzido, buscando otimizar os processos.

Observando o antigo e o novo organograma, caracterizados respectivamente de 1 e $2^{24}$, e disponíveis nos anexos 1 e 2 , também respectivamente, é possível considerar a extensão e a complexidade da empresa $X$. Analisaremos os organogramas, buscando destacar suas modificações mais relevantes.

Até o ano de 2012, o organograma 1, atual em dezembro de 2012, a empresa $X$ estava formada por: 1 presidência (com 1 assessoria, 6 superintendências e 10 departamentos); abaixo da presidência encontravam-se: 5 diretorias; 46 assessorias; 21 superintendências (com 13 assessorias); 53 departamentos e 170 divisões.

Já no organograma 2, atual em julgo de 2013, observamos que esses números foram reduzidos para: 1 presidência (com 2 assessorias, 3 superintendências e 4 gerências). Abaixo dela encontramos: 5 diretorias; 46 assessorias; 18 superintendências; 56 gerências (substituindo os antigos departamentos) e 138 divisões.

Em termos de redução, observa-se que ocorreu um corte de 44 áreas diversificadas, dentre elas: 3 superintendências ligadas à presidência, 6

\footnotetext{
${ }^{24}$ Para preservar a identidade da empresa, retiramos o nome da mesma, bem como o nome de seu presidente e diretores.
} 
departamentos, agora chamados de gerências e 3 superintendências, além de 32 divisões.

Com isso, um número elevado de trabalhadores foram remanejados de suas funções e, ainda, com alguns acumulando novas atribuições e tarefas para atenderem a processos que foram associados a outros, na busca pela otimização de funções e redução dos custos.

\section{3. \\ A representação do trabalho diante da gestão por processos}

Neste ponto da pesquisa buscamos aprofundar quais os rebatimentos da gestão por processos no trabalho, que vem se modificando ao longo dos anos. Traçaremos ainda um paralelo com modelos de gestão e produção comentados no segundo capítulo, para buscar identificar tal modificação, considerando, ainda, que tipo de mudança real ela representa para o trabalho na empresa $X$, ou se é mais uma estratégia de sobrevivência do modelo capitalista, como já mencionado nesta dissertação.

Vejamos o que dizem os trabalhadores e gestores.

Em um primeiro momento desta fase das entrevistas percebe-se novamente uma aceitação unânime relacionada à gestão por processos, ao associá-la ao trabalho de uma forma geral, ou seja, aos processos existentes na empresa. Segundo o trabalhador 3, o novo processo "evita retrabalhos, pois consegue definir atribuições e responsabilidades em diversos níveis hierárquicos" (Pesquisa de campo, entrevista com trabalhador efetivo 3 , setor de transporte).

Outra fala do mesmo trabalhador reforça esta última, onde o trabalhador vislumbra um "[...] fluxo de trabalho menos segmentado, e consequentemente a empresa será mais ágil", apontando ainda que "[...] atividades administrativas de uma empresa estatal caracterizam-se por processos longos e burocráticos" (Pesquisa de campo, entrevista com trabalhador efetivo 3, setor de transporte).

O gerente $Y$ também associou a questão das tarefas desenvolvidas ao fluxo que as mesmas, integradas, podem produzir para melhorar o desempenho 
geral da empresa. Sobre a influência que a gestão por processos terá no trabalho ele responde que:

\begin{abstract}
$\mathrm{Na}$ prática: alinhando melhor os processos com as estratégias, eliminando custos desnecessários, permitindo uma melhor coordenação e comunicação entre as áreas funcionais, viabilizando as necessidades de mudança, identificando processos em duplicidade, inconsistentes ou inexistentes e promovendo a melhoria contínua dos processos (Pesquisa de campo, entrevista com gerente $\mathrm{Y}$, responsável pela implementação da nova gestão por processos).
\end{abstract}

Essas impressões dos trabalhadores levou a pesquisadora a resgatar um período histórico da empresa $X$, quando esta esteve à beira da privatização, e onde a estratégia primeira para privatizar foi o sucateamento da mesma, que ainda se reflete nos processos da empresa até hoje.

Outro resgate necessário se refere a "incompetência" atribuída ao Estado, no caso o governo federal, para administrar empresas como esta, seguindo a mesma lógica vista em Behring (2001), quando a autora discorre sobre a entrada da reestruturação produtiva no Brasil, ainda na década de 80 , que desembocou no endividamento das empresas, como já visto nos capítulos iniciais desta dissertação.

De qualquer forma, estas mudanças na visão dos entrevistados ainda não tiveram rebatimentos diretos no trabalho considerado como tarefa. Contudo, abordando o trabalho enquanto categoria, ou seja, com as determinações presentes na realidade da empresa $X$, o discurso muda e a fala de todos remete ao acordo coletivo de trabalho, onde o direito do trabalho é colocado como principal elemento de defesa dos direitos, cada vez mais reduzidos e sem ganhos salariais reais.

Segundo o trabalhador 4, a gestão por processos pode significar "uma máscara para outras coisas que vêm por aí, não é nada transparente" (Pesquisa de campo, entrevista com trabalhador contratado 4, setor de análise de sistemas). 


\section{4. Como fica o trabalhador?}

Por fim, diante de tantos modelos de acumulação capitalista, como fica o trabalhador na engrenagem da gestão por processos? Existe trabalho decente dentro deste novo sistema? Dessa foram, se faz importante também analisar neste item o direito no trabalho, através dos Acordos Coletivos de Trabalho, mencionados nas entrevistas.

Não pretendemos aqui responder por definitivo a essas perguntas, visto que a crítica acerca da gestão por processos por parte dos entrevistados é baixa, o que pode denotar desconhecimento sobre a "novidade" ou mesmo um consentimento obtido pela empresa através da própria estratégia adotada.

Percebe-se uma aceitação deste novo sistema, acreditando que será mais produtivo, para o trabalho e para a empresa. Os trabalhadores (dos mais diversos estatutos) não se vêm, portanto, inseridos nesse processo como principal agente de mudanças, acreditando que essa reestruturação na empresa $X$ pode representar uma oportunidade de aprendizado, com visão macro do processo. Segundo o trabalhador 1, o processo "facilitará e organizará o trabalho a ser realizado. As atividades tornam-se mais visíveis e interligadas" (Pesquisa de campo, entrevista com trabalhador efetivo 1, setor jurídico).

Ainda acreditando nas possibilidades do "treinamento", outro trabalhador completa, de forma que denota "naturalização" do processo em andamento, sem atentar para os riscos que tal estratégia pode representar para os próprios trabalhadores, "eu acho que vai depender de como a empresa vai investir em treinamento e premiar os funcionários mais destacados. Vai ter mais competitividade interna" (Pesquisa de campo, entrevista com trabalhador efetivo 5 , setor de patrimônio).

Esta fala está diretamente relacionada a uma prática muito característica de uma gestão onde opera, melhor dizendo, um modelo de produção que incentiva a participação dos trabalhadores no processo de forma a assumirem a visão da empresa sobre o seu trabalho, ou seja, permanece uma relação onde o trabalhador "veste a camisa da empresa", ajudando-a com o sucesso de sua produção e, assim, gerando lucro que só será acessível pelo trabalhador através de benesses e não ganhos reais e garantia de direitos, estes cada vez mais 
substituídos por premiações, uma clássica característica da economia política liberal e que se renova com as investidas da reestruturação produtiva e das estratégias em curso.

Analisando a questão do corte de pessoal percebe-se que existem justificativas distintas para tal decisão. De um lado, a empresa, representada aqui pelo seu gerente, coloca que para que os objetivos da gestão por processos sejam alcançados, se faz necessária a colaboração da força de trabalho. Segundo ele:

O mais significativo, talvez, seja a possibilidade do empregado poder perceber, de forma cada vez mais clara, a contribuição do seu trabalho para com os demais e a organização, em uma visão orientada para resultados (Pesquisa de campo, entrevista com gerente $\mathrm{Y}$, responsável pela implementação da nova gestão por processos).

Ele ainda complementa que a dificuldade maior a ser enfrentada pelos trabalhadores será a mudança, o que considera natural para o ser humano.

Ao ser perguntado sobre os impactos previstos para a classe trabalhadora, este mesmo gerente respondeu:

$\mathrm{Na}$ empresa $X$ existia uma cultura onde $\mathrm{o}$ trabalhador exercia sua atividade específica, determinada. Hoje, a gestão por processos irá retirá-los da zona de conforto. As pessoas mimadas sentirão (Pesquisa de campo, entrevista com gerente $\mathrm{Y}$, responsável pela implementação da nova gestão por processos).

Isso se referindo às novas e cumulativas atribuições para o trabalhador, justificando que em outras empresas é assim que funciona.

Nesse mesmo sentido, há uma visão muito contraditória entre os sindicalistas entrevistados. $O$ sindicalista $A$ acredita que:

O empregado tem mais tempo para criar. Antes ele tinha um trabalho braçal, pensava menos. Ele hoje teria mais tempo para pensar. As maiores dificuldades é você transmitir como o processo funciona. Ele hoje tem que ter uma visão do todo, principalmente saber que são processos interligados, todos precisam saber disso (Pesquisa de campo, entrevista com sindicalista A).

Já o sindicalista B considera que os empregados terão que se adaptar a um cenário onde haverá uma diminuição de pessoas, demissões e, 
consequentemente, acúmulo de funções, conforme já ressaltamos, para aqueles que permanecerem como novos concursados. Segundo ele, "eles querem atingir só o pessoal, se pudessem reduziriam salário, tickets e qualquer outro benefício, eles reduziriam ou acabariam. Isso é reestruturação? (Pesquisa de campo, entrevista com sindicalista B).

Esta fala expressa não só um trabalho precarizado por falta e/ou retirada de direitos no trabalho. Mas a própria produção do desemprego, expressando também a perda do direito ao trabalho, tornando impossível a discussão da promoção de trabalho decente, uma vez que a redução de pessoal, assim como os benefícios, são sempre os primeiros cortes a serem realizados, e são tratados ainda como fatalidade para a empresa e seus empregados, tudo em prol da "sobrevivência da companhia". Segundo o sindicalista A "você passa 20 anos aqui dentro como contratado, você acha que o mercado te absorve? Operador ou mão de obra especializada absorve, agora administrativo não, vai ficar desempregado" (Pesquisa de campo, entrevista com sindicalista A).

Duas características do trabalho precarizado se fazem presentes na afirmação acima. Uma referente às demissões eminentes, e a outra diz respeito a divisão ocorrida entre a classe trabalhadora diante do trabalho terceirizado, que, como já visto aqui, pode ser considerado por alguns autores como a principal característica do trabalho precário, com protagonismo no mundo do trabalho a partir da reestruturação produtiva.

Essas características estão cada vez mais presentes na empresa X, demostrando que a flexibilização do trabalho enquanto categoria divide cada vez mais os trabalhadores, já diferenciados pelo mercado. Aqueles centrais, com características mais intelectualizadas e de maior interesse para a empresa, são facilmente absorvidos. Porém, os trabalhadores periféricos, considerados braçais ou de apoio, como aponta o sindicalista $\mathrm{A}$, como os administrativos contratados pela empresa $X$, sofrerão na fila do desemprego ou, ainda, se submeterão ao subemprego. Segundo ele:

O cara que é contratado tá numa situação pior ainda, você dividiu a família, o empregado não se preocupa com o contratado, aquele que conquistou o direito de entrar na empresa não se preocupa com o outro. Serão demitidos 1400 trabalhadores contratados até 2018 (Pesquisa de campo, entrevista com sindicalista A). 
O mesmo sindicalista aponta, ainda, que a empresa, com tais atitudes, segue o caminho da privatização, por desenhar, com a gestão de processos, características de empresa privada, citando como exemplo os sistemas já implantados de $\mathrm{SAP}^{25}$, que para os empregados representou um controle maior de seus horários, impedindo a flexibilização antes permitida de utilizar seu horário de trabalho para ir ao médico ou realizar exames a partir da negociação com a gerência. Hoje, este sistema faz o desconto imediato nas horas acumuladas pelos trabalhos extras dos empregados.

E prossegue afirmando, "a gente já sabe onde vai dar, na privatização, redução de custos total. Se privatizar, quem está aí há muitos anos irá se sentir um inútil, por que ele não foi preparado para isso" (Pesquisa de campo, entrevista com sindicalista A).

Não obstante as ponderações do sindicalista A, apenas dois trabalhadores apontaram a gestão por processos como prejudicial ao trabalhador:

\begin{abstract}
Os principais ativos da empresa, que são os funcionários, não participam deste processo, deveriam ser chamados. Só os cabeças da empresa, de forma política, participaram do processo decisório (Pesquisa de campo, entrevista, com trabalhador efetivo 6 , setor de pagamentos).
\end{abstract}

Existem características semelhantes entre a gestão por processos e outros modelos de produção. Todos necessitam de uma "participação" do efetivo de trabalhadores para que os modelos de gestão obtenham sucesso, ou, pelo menos, de seu consentimento, já que não existe participação no processo de decisão, apenas concordância diante da promessa de melhores condições de trabalho ao reorganizar a produção com a nova gestão.

Ou seja, a mudança, como em qualquer modelo de gestão capitalista, tem o consentimento da grande maioria de trabalhadores, que "compram o discurso" da empresa, esperando ganhos após produzirem de acordo com a nova gestão, sem perceber que cairão num abismo de acúmulo de funções, tornando-os cada vez mais polivalentes e flexíveis, elementos fundamentais de exploração. Segundo o trabalhador 4, "não vejo até agora nenhum benefício, só malefício. O trabalho está dobrando, estão trabalhando desmotivados. Aquele

\footnotetext{
${ }^{25}$ SAP Significa sistema de gestão integrada.
} 
que fazia duas coisas vai passar a fazer 4" (Pesquisa de campo, entrevista com trabalhador efetivo 4 , setor de análise de sistemas).

Por essa razão, entendemos que a gestão por processos está cumprindo seu papel. Ainda que não tenha chegado a sua total implementação, ela já demonstra seus principais objetivos: a otimização dos processos, o aumento da produção e a diminuição dos recursos utilizados. 


\section{5 \\ Considerações Finais}

O trabalho ora apresentado destinou-se a analisar as possibilidades de promoção do trabalho decente a partir da nova gestão por processos, em desenvolvimento na empresa $X$ como estratégia para se colocar de forma reestruturada no mercado competitivo.

A gestão por processos na empresa x está em vias de implementação, portanto não pretendemos aqui responder de forma definitiva se há possibilidade de trabalho decente após sua reestruturação, orientada por esta nova forma de gestão. O que analisamos de fato, a partir da vivência dos trabalhadores e representantes da empresa, se refere às novas práticas adotadas por ela, através da nova gestão, considerando a sua história e posição estratégica no setor elétrico brasileiro.

Buscamos demonstrar, com base nas premissas teóricas apresentadas, as modificações sofridas pela empresa, e as consequências para o trabalho e seus trabalhadores, após o processo de implementação da reestruturação produtiva no Brasil, na década de 1990, norteada por modelos econômicos e sociais que imprimem a busca pela acumulação de capital.

Procurou-se, ainda, entender se há possibilidade de existir trabalho decente, conforme preconizado pela OIT, na relação capital $x$ trabalho na forma com que está constituído na organização da produção, na lógica capitalista, tomando como exemplo o caso da reestruturação da empresa $X$.

A empresa $X$ foi escolhida por diversos fatores. Primeiro, pela sua história de resistência diante das inúmeras tentativas de enquadramento ao modelo neoliberal de privatização, característico da era FHC, na década de 1990. Segundo, por representar para este estudo o espaço de experiência profissional desta pesquisadora.

Refeito o trajeto da pesquisa, considera-se que sua produção, baseada na análise qualitativa, levou a refletir sobre a questão do trabalho decente, de forma geral, considerando as particularidades da empresa $X$, sobretudo no aprofundamento de sua reestruturação pela gestão por processos. 
Vimos, no capítulo 4, através da análise do organograma, que a gestão por processos vem desenhando uma empresa $X$ mais enxuta e com seus processos mais otimizados, ou seja, produzindo mais com menos.

Pois bem, ser mais enxuta significa uma redução de recursos materiais e humanos, como vimos no decorrer da pesquisa. É neste lugar que se debruçou a análise deste trabalho.

Os cortes, que traduzem redução de custos, representam uma característica não só da gestão por processos, mas dos modelos de produção capitalista. Contudo, reforça, em termos de trabalho, uma precarização ainda maior se considerarmos o corte de $30 \%$ a $40 \%$ da mão de obra desta empresa, o que já vem ocorrendo nos últimos 2 anos.

Ou seja, revisitando a questão colocada no capítulo 2, sobre o direito ao trabalho e do trabalho, onde apontamos a importância do acesso ao emprego e da melhoria de suas condições no espaço da empresa, torna-se notória a incapacidade da garantia de tais direitos pela empresa $X$, seja pela promoção do desemprego, pelos cortes de benefícios ou pela perda de ganhos reais em termos de salário, em discussão no Acordo Coletivo de Trabalho (ACT), que vem perdendo força ao longo dos anos, como podemos observar nas tabelas do anexo 5, que desenha a trajetória dos acordos coletivos da empresa.

Considerando que o trabalho decente, definido como um trabalho adequadamente remunerado, exercido em condições de liberdade, equidade e segurança, capaz de proporcionar condições dignas de vida, a OIT, junto com o governo brasileiro, organizou uma agenda onde define três prioridades. Dentre elas se destaca a geração de mais e melhores empregos, com igualdade de oportunidades e de tratamento, conforme abordado nesta dissertação.

Porém, a discussão do trabalho decente não satisfaz a compreensão sobre a dinâmica do mercado de trabalho. Observou-se, com a experiência da empresa X, que a busca pela "qualidade do emprego" estudada por Mocelin (2011) "configura um modelo analítico mais amplo", quando o trabalho decente seria apenas mais uma categoria, assim como outras. Contudo, a questão da qualidade do emprego não foi tratada aqui como principal categoria de análise, mas ela serve de base para o desenvolvimento de uma análise crítica acerca do trabalho decente. 
Compreendendo que o trabalho decente inclui todas as formas de emprego, tendo a pretensão de dar qualidade ao emprego, percebe-se, com a experiência da reestruturação na empresa $X$, que essa qualidade está distante de se efetivar, uma vez que a otimização na produção, incluída a redução de quadro funcional, demonstra uma empresa administrada pelo governo federal, porém com característica de empresa privada, competindo com várias outras no mercado, adotando a mesma lógica de produção, revelando uma empresa pública de caráter privado, para atender as exigências do mercado.

Por fim, a discussão do trabalho decente engloba uma ideia de emprego típico, onde existem relações contratuais e salariais estáveis entre empregado e empregador, assim como estabilidade no emprego, característica da era industrial do século $\mathrm{XX}$, ainda que em alguns períodos e empresas não existisse ambiente adequado de trabalho.

Essa ideia não atende de forma plena a discussão atual de desenvolvimento de um mercado de trabalho decente. Ou seja, não existirá trabalho decente enquanto não houver uma análise crítica acerca do mercado, destacando quais as possibilidades de existência de trabalhos de qualidade e de forma ampliada. 


\section{Referências Bibliográficas}

ABRAMOVICH, V.; COURTIS, C. Los derechos sociales como derechos exigibles. Madrid: Editorial Trotta, 2004.

ALVES, G. O novo (e precário) mundo do trabalho: reestruturação produtiva e crise do sindicalismo. São Paulo: Boitempo Editorial, 2000.

ANDERSON, P. Balanço do neoliberalismo. In: SADER, E; GENTILLI, P. (Orgs.). Pós-neoliberalismo: as políticas sociais e o Estado democrático. Rio de Janeiro: Paz e Terra,1995.

ANTUNES, R. Adeus ao trabalho? As metamorfoses do mundo do trabalho. 2 ${ }^{\mathrm{a}}$. ed. São Paulo: Cortez, 2000.

. Os sentidos do trabalho: ensaio sobre a afirmação e a negação do trabalho. São Paulo: Boitempo Editorial, 1999.

. O novo sindicalismo. São Paulo: Scritta, 1996.

BASTOS, P. P. Z. A construção do nacional-desenvolvimentismo de Getúlio Vargas e a dinâmica de interação entre Estado e mercado nos setores de base. EconomiA, Selecta, Brasília (DF), v.7, n.4, p.239-275, dezembro 2006.

BEHRING, E. R. O Brasil e a mundialização do capital: privatização, deslocalização e flexibilização das relações de trabalho, In: SERRA, R. S. (Org). Trabalho e reprodução: enforques e abordagens, Rio de Janeiro: Cortez, 2001.

BENJAMIM, C. Gênese, dinâmica e sentido da crise energética brasileira. Caros Amigos, 2001.

BOGUS, L.; PAULINO, A. Y. (Org.). Políticas de emprego, políticas de população e direitos sociais. São Paulo: Educ, 1997.

BOLTANSKI, L. Les Cadres: la formation d'un groupe social. Paris: Minuit, 1982.

BOLTANSKI, L.; CHIAPELLO, E. Le nouvel esprit du capitalisme. Paris: Gallimard, 1999. 
BOLTANSKI, L.; THÉVENOT, L. De la justification. Paris: Gallimard, 1991.

BRANCO, U. N. da R. As modificações no mundo do trabalho e seus reflexos na saúde do trabalhador: $O$ exemplo de uma empresa estatal. Trabalho de Conclusão de Curso. Faculdade de Serviço Social/UERJ. Rio de Janeiro, 2002.

BRASIL. Lei № 9.074, de 07 de julho de 1995. Estabelece normas para outorga e prorrogações das concessões e permissões de serviços públicos e dá outras providências.

Medida Provisória № 579, de 11 de setembro de 2012. Dispõe sobre as concessões de geração, transmissão e distribuição de energia elétrica, sobre a redução dos encargos setoriais, sobre a modicidade tarifária, e dá outras providências.

Concessões de energia elétrica. Ministério das Minas e Energia, $2012 . \quad$ Disponível em> <http://www.mme.gov.br/mme/menu/concessoes.html>. Acesso em: 10 jan. 2013.

BRAVERMAN, H. Trabalho e capital monopolista. A degradação do trabalho no século XX. Rio de Janeiro: Zahar, 1997.

BRITO, E. H. G. de; MENDES, A. Os impasses da política econômica brasileira nos anos 90 . In: Política fiscal e a dinâmica das contas públicas: os impasses da economia brasileira nos anos 80 e 90 . São Paulo. FAAP, 2003.

CASTELLS, M. A sociedade em rede. São Paulo: Paz e Terra, 1999.

CATTANI, A. D.; HOLZMANN, L. Dicionário de trabalho e tecnologia. Porto Alegre, Zouk, 2011.

CENTRAL ÚNICA DOS TRABALHADORES (CUT). Cartilha do trabalho decente. São Paulo: CUT, 2011. Disponível em: <http://portal.mte.gov.br/data/files/8A7C812D302E6FAC013045FF8FB30 B3D/CUT_cartilha-trabalho-decente-na-estrategia-da-cut.pdf>. Acesso em: 18 jul. 2013.

CESAR, M. de J. Serviço Social e reestruturação industrial: requisições, competências e condições de trabalho profissional. In: MOTA, A. E. (Org.). A nova fábrica de consensos. São Paulo: Cortez, 1998. 
DAGNINO, E. (Org.). Anos 90. Política e sociedade no Brasil. São Paulo: Brasiliense, 1994.

DEJOURS, C. A banalização da injustiça social. Rio de Janeiro: Fundação Getúlio Vargas, 2001.

DEPARTAMENTO INTERSINDICAL DE ESTATÍSTICA E ESTUDOS SOCIOECONÔMICOS (DIEESE). A Situação do trabalho no Brasil na primeira década dos anos 2000. São Paulo: DIEESE, 2012.

DRUCK, M. G. Terceirização: (des)fordizando a fábrica: um estudo crítico do complexo petroquímico. São Paulo: Boitempo,1999.

DRUCK, M. G; FRANCO, T. (Orgs.). A perda da razão social do trabalho: terceirização e precarização. São Paulo: Boitempo, 2007.

ELETROBRAS. A Eletrobrás e a história do setor de energia elétrica no Brasil. Rio de Janeiro: Centro da Memória da Eletricidade no Brasil, 1995.

GASPARI, E. A ditadura escancarada. São Paulo: Cia. das Letras, 2002.

GORENDER, J. Marxismo sem utopia. Editora Ática, 1999.

GRAMSCI, A. Concepção dialética da história. Rio de Janeiro: Civilização Brasileira, 1978.

GUATARRI, F. Revolução molecular: pulsões políticas do desejo. (Tradução Suely Belinha Rolnik). 3. ed. São Paulo: Brasiliense, 1987.

GUERRA, Y. Direitos sociais e sociedade de classes: o discurso do direito a ter Ddireitos. In: Ética e direitos: ensaios críticos. $2^{\underline{a}}$ ed. Rio de Janeiro: Lumen Juris, 2010.

GONÇALVES, J. Processo, que processo? RAE - Revista de Administração de Empresas, v. 40, n. 4, p. 8-19, out./dez. 2000.

HARVEY, D. A condição pós-moderna. São Paulo: Loyola, 1993.

O enigma do capital e as crises do capitalismo. São Paulo: Boitempo, 2010.

INSTITUTO BRASILEIRO DE GEOGRAFIA E ESTATÍSTICA (IBGE). Censo 2010. Disponível em: <http://censo2010.ibge.gov.br/>. Acesso em: 10 nov. 2012. 
LEANDRO, L. A. L. Relações entre ética e educação ambiental: perspectivas de educadores ambientais no ensino superior. Niterói: Universidade Federal Fluminense, 2005.

MARQUES, M. Uma dimensão do direito "AO" e "DO" trabalho In: Ética e direitos: ensaios críticos. $2^{\mathrm{a}}$ ed. Rio de Janeiro: Lumen Juris, 2010.

MARX, K. O Capital: crítica da economia política. São Paulo: Nova Cultural, 1988. Livro 1, v.1, tomos 1 e 2.

MAYRING, P. Einführung in die qualitative Sozialforschung. [Introdução à pesquisa social qualitativa]. 5a ed. Weinheim: Beltz, 2002. Disponível em: <http://www.unb.br>. Acesso em: 10 abr. 2013.

MENDONÇA, S. R. de. As bases do desenvolvimentismo capitalista dependente: da industrialização restringida à internacionalização In: História geral do Brasil. Rio de Janeiro: Campus, 1998.

MÉSZÁROS, I. A crise estrutural do capital. São Paulo: Boitempo, 2011.

MOCELIN, D. G. Do trabalho precário ao trabalho decente? A qualidade do emprego como perspectiva analítica. Revista de Ciências Sociais, Fortaleza, v.42, n.2, jul/dez, 2011, p.47-62.

NETTO, J. P. Crise do socialismo e ofensiva neoliberal. São Paulo: Cortez, 1993 (Coleção Questões da nossa época, v. 20).

ORGANIZAÇÃO INTERNACIONAL DO TRABALHO (OIT). Recomendação no 198. 95a Conferência Mundial, de 15 de junho de 2006. Disponível em: <http://www.oit.org.br/>. Acesso em: 07 out. 2012.

ROCHA, P. Sincronismo Organizacional (IL-Video - Interactive. Learning Vídeo). Disponível em: <www.sincronismoorganizacional.com.br>, 2004.

Gestão por processos. Rio de Janeiro: Fórum de Gestão por Processos. 2012.

ROCHA, P.; ALBUQUERQUE, A. Sincronismo organizacional. Rio de Janeiro: Saraiva, 2007.

ROSENFIELD, C.; NARDI, H. Competência. In: CATTANI, A. D.; HOLZMANN, L. (Orgs.). Dicionário de trabalho e tecnologia. Porto Alegre: Editora da UFRGS, 2006. 
SADER, E. A transição do Brasil: da ditadura a democracia?. São Paulo: Atual Editora, 1991.

SALLUM JR., B. O Brasil sob Cardoso: neoliberalismo e desenvolvimentismo. Tempo Social Rev. Sociol. USP, São Paulo. 1999.

SANTOS, B. Reinventar a democracia: entre o pré-contratualismo e o pós-contratualismo. In: A crise dos paradigmas em Ciências Sociais e os desafios para o século XXI. Rio de Janeiro: Contraponto, 1999.

SENNETT, R. A cultura do novo capitalismo. São Paulo: Record, 2006.

TEIXEIRA, F. J. S.; OLIVEIRA, M. de (Orgs.). Neoliberalismo e reestruturação produtiva: as novas determinações do mundo do trabalho. São Paulo: Cortez, 1996.

VÁRIOS AUTORES. Serviço Social e Sociedade - Mundo do Trabalho. Ano XVII, n. 52. São Paulo: Cortez, 1996.

VASAPOLLO, L. A precariedade como elemento estratégico determinante do capital. Pesquisa \& Debate, SP, v. 16, n. 2(28), p. 368-386, 2005. 
Anexos

7.1.

Anexo 1 - Organograma 1 da empresa X, de dezembro de 2012

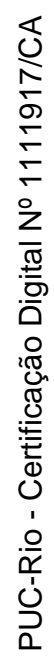

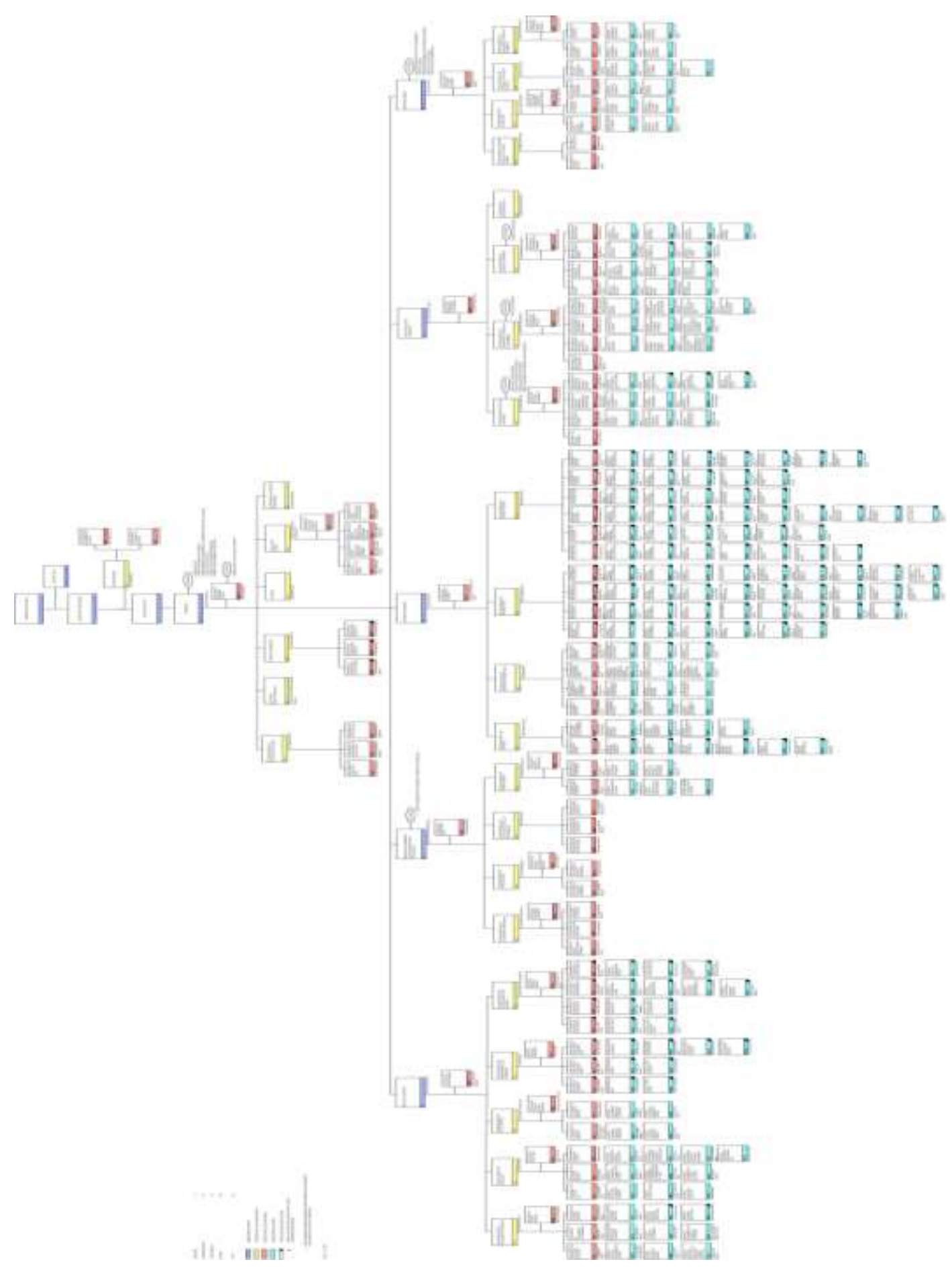


7.2.

Anexo 2 - Organograma 2 da empresa X, de julho de 2013

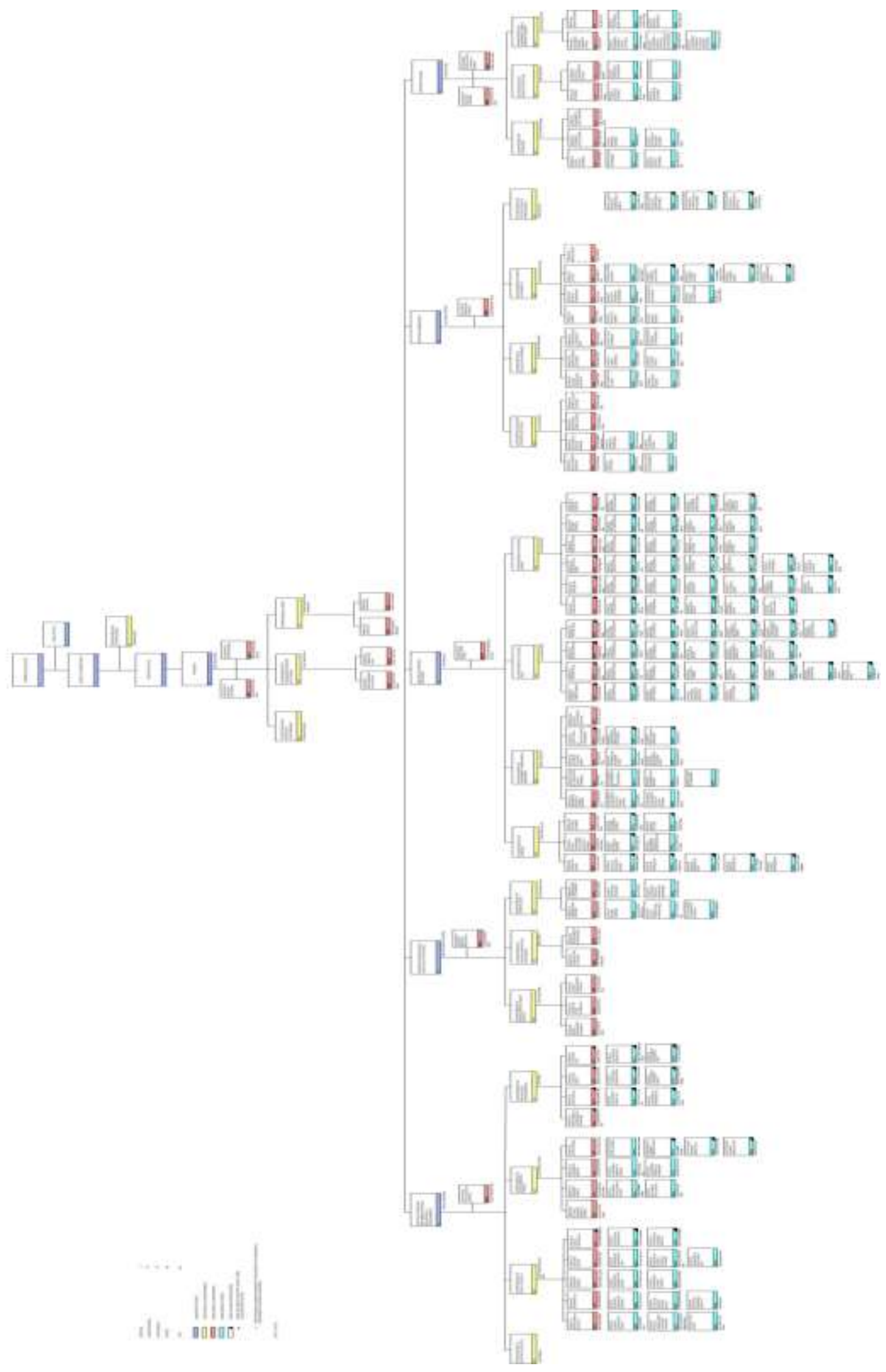




\section{3. \\ Anexo 3 - Roteiro de entrevista}

•Como você vê a gestão por processos?

-O que motivou esta empresa a adotar a gestão por processos?

-Quais as necessidades da gestão por processos para atingir seu sucesso? Como ela deve funcionar efetivamente?

- Considera que esta empresa atingirá seus objetivos com a nova reestruturação? Quais são as metas desejáveis?

-Quais as necessidades que esta empresa tem hoje para cumprir suas metas dentro da perspectiva da reestruturação?

-Quais as maiores dificuldades enfrentadas por esta empresa desde o ano 2000 até para que se chegasse à necessidade da implantação da gestão por processos?

- Estabeleça uma relação entre a natureza desta empresa e as novas exigências do mercado em relação a produção de energia elétrica?

-Acredita que a gestão por processos pode fazer com que a empresa se desenvolva? Em quais aspectos?

- De que maneira a gestão por processos influenciará nos diversos processos de trabalho na empresa?

- O que representa a gestão por processos para o empregado? Quais os benefícios e dificuldades?

-Quais as mudanças necessárias que os empregados terão de se adaptar para tal implementação? Quais as implicações para eles? 


\section{4. \\ Anexo 4 - Termo de Consentimento Livre e Esclarecido (TCLE)}

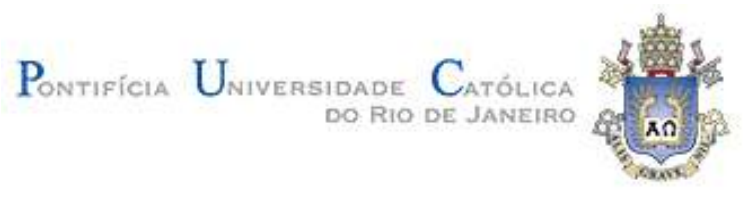

Pontifícia Universidade Católica do Rio de Janeiro

Departamento de Serviço Social

Programa de Pós-Graduação em Serviço Social

Pesquisa: Novas Gestões Empresariais por Processos: trabalho decente ou trabalho precário?

Pesquisador: Ursula Nacimento da Rocha Branco

Orientadora: Profa. Dra. Inez Stampa

\section{Termo de Consentimento Livre e Esclarecido}

Declaro, por meio deste termo, que concordei em ser entrevistado(a) na pesquisa de campo referente à dissertação intitulada "Novas Gestões Empresariais por Processos: trabalho decente ou trabalho precário?", desenvolvida pela mestranda Ursula Nascimento da Rocha Branco, aluna do Programa de Pós-Graduação em Serviço Social da PUC-Rio.

Fui informado(a), ainda, de que a pesquisa é orientada pela professora Inez Terezinha Stampa, a quem poderei contatar/consultar a qualquer momento que julgar necessário através do telefone (21) 3527-1290 ou pelo e-mail inestampa@puc-rio.br. Também fui informado(a) sobre os contatos do pesquisadora responsável: Ursula Nascimento da Rocha Branco, a quem poderei contatar/consultar a qualquer momento que julgar necessário pelo telefone (21) 98075435 ou pelo e-mail ursulabranco@gmail.com.

Afirmo que aceitei participar por minha própria vontade, sem receber qualquer incentivo financeiro e com a finalidade exclusiva de colaborar para o sucesso da pesquisa. Fui informado(a) dos objetivos estritamente acadêmicos do estudo, que, em linhas gerais, visa conhecer e problematizar, através do discurso e das ações desta empresa de energia elétrica, a implementação da gestão por processos e quais as consequências da desta implementação para a empresa e seus empregados.

Fui também esclarecido(a) de que os usos das informações por mim oferecidas estão submetidos às normas éticas destinadas à pesquisa envolvendo seres humanos, da Comissão Nacional de Ética em Pesquisa (CONEP).

Minha colaboração se fará de forma anônima, por meio de entrevistas, podendo ser gravadas a partir da assinatura desta autorização. As informações obtidas através desta pesquisa serão confidenciais e fica assegurado o sigilo sobre a minha participação. Fui informado(a) que a gravação visa melhorar a qualidade e fidelidade dos dados coletados e que após a gravação a entrevista será transcrita e o acesso e a análise aos dados coletados se farão apenas pela pesquisadora e/ou orientadora.

Estou ciente de que, caso eu tenha dúvida ou me sinta prejudicado(a), poderei contatar a pesquisadora responsável ou sua orientadora, ou ainda o Programa de Pós-Graduação em Serviço Social da PUC-Rio, situado na Rua Marquês de São Vicente, 227, Vila dos Diretórios, Gávea, Rio de Janeiro (RJ), telefone (21) 3527-1290, fax (21) 3527-1291.

A pesquisadora responsável me entregou uma cópia assinada deste Termo.

Fui ainda informado(a) de que posso me retirar deste estudo a qualquer momento, sem prejuízo para minha relação profissional ou sofrer quaisquer sanções ou constrangimentos.

Rio de Janeiro, de de

Assinatura do(a) Participante:

Assinatura da Pesquisadora: 
7.5.

Anexo 5 - Tabela comparativa de benefícios adquiridos através do Acordo Coletivo de Trabalho (ACT)

\begin{tabular}{|c|c|c|c|c|c|c|}
\hline ACT & Mês & \begin{tabular}{|c|} 
Indice \\
Concedido \\
$(\%)$
\end{tabular} & $\begin{array}{c}\text { Ganho Real } \\
\text { x Inflação }\end{array}$ & Abono Salarial & Justificativa do Abono & $\begin{array}{l}\text { Inflaçāo do } \\
\text { Periodo } \\
\text { IPCA }(\%)\end{array}$ \\
\hline $94 / 95$ & Novembro & 15,67 & - & - & - & $13,39^{1}$ \\
\hline $95 / 96$ & Novembro & 17,25 & - & $\begin{array}{l}70 \% \text { da remuneração }+ \\
\operatorname{RS} \$ 400,00\end{array}$ & $\begin{array}{c}\text { Alteração nos adiantamentos de } \\
\text { férias, da gratificaçāo natalina e } \\
\text { do salário mensal }\end{array}$ & 24,21 \\
\hline $96 / 97$ & Novembro & 3,27 & - & $\begin{array}{c}60 \% \text { da remuneração }+ \\
\operatorname{R\$ } 250,00\end{array}$ & $\begin{array}{c}\text { Venda do auxilio alimentaçåo } \\
\text { pago nas férias e extinşă do } \\
\text { adiantamento quinzenal dos. } \\
\text { salários. }\end{array}$ & 12,02 \\
\hline $97 / 98$ & Novembro & 1,00 & - & $\begin{array}{c}47 \% \text { da remuneraça + } \\
\operatorname{R} \$ 400,00\end{array}$ & $\begin{array}{l}\text { Alteraç̧̃o da distribuição do } \\
\text { auxilio alimentação de } 22 \\
\text { tiquetes/mès para um por dia } \\
\text { trabalhado. }\end{array}$ & 5,21 \\
\hline $98 / 99$ & \multicolumn{6}{|c|}{ Não houve Acordo Coletivo neste periodo, devido à mudança da data-base para maio. } \\
\hline $99 / 00$ & Maio & - & - & Uma remuneraçāo & Mudança da data-base & 7,49 \\
\hline $00 / 01$ & Maio & 5,06 & - & Uma remuneração & Perdas salariais & 6,77 \\
\hline $01 / 02$ & Maio & 6,00 & $\cdot$ & Uma remuneração & Perdas salariais & 6,61 \\
\hline $02 / 03$ & Maio & 6,00 & $=$ & Uma remuneraçāo & Perdas salariais & 7,98 \\
\hline $03 / 04$ & Maio & $10,50^{2}$ & - & Uma remuneraçāo & Perdas Salariais & 16,77 \\
\hline
\end{tabular}

\begin{tabular}{|c|c|c|c|c|c|c|}
\hline $\mathrm{ACT}$ & Mês & $\begin{array}{c}\text { Indice } \\
\text { Concedido } \\
(\%)\end{array}$ & $\begin{array}{c}\text { Ganho Real } \\
\text { x Inflaçăo }\end{array}$ & Abono Salarial & Justificativa do Abono & $\begin{array}{l}\text { Inflação do } \\
\text { Periodo } \\
\text { IPCA }(\%)\end{array}$ \\
\hline $04 / 05$ & Maio & 5,26 & - & $\begin{array}{c}60 \% \text { da remuneração + } \\
\text { RS } 1.000,00 \text { (limitado a } \\
\text { uma remuneração) }\end{array}$ & - & 5,26 \\
\hline $05 / 06$ & Maio & 8,07 & $1,50 \%$ & $\begin{array}{c}30 \% \text { da remuneração + } \\
\text { Rs } 800,00 \text { (limitado a } \\
\text { uma remuneração) }\end{array}$ & - & 8,07 \\
\hline $06 / 07$ & Maio & 4,63 & $2,26 \%$ & $\begin{array}{c}10 \% \text { da remuneração }+ \\
\text { R\$ } 900,00\end{array}$ & - & 4,63 \\
\hline $07 / 08$ & Maio & 3,00 & $2,00 \%$ & $\begin{array}{c}7,5 \% \text { da remuneraçâo + } \\
\text { R\$ } 1000,00\end{array}$ & - & 3,00 \\
\hline $08 / 09$ & Maio & 5,04 & $1,96 \%$ & $\begin{array}{c}7,5 \% \text { da remuneração + } \\
\text { RS } 2000,00\end{array}$ & - & 5,04 \\
\hline $09 / 10$ & Maio & 5,53 & $1,70 \%$ & $\begin{array}{c}7,5 \% \text { da remuneração + } \\
R \$ 2000,00\end{array}$ & - & 5,53 \\
\hline $10 / 11$ & Maio & 5,26 & $1,00 \%$ & $\begin{array}{c}7,5 \% \text { da remuneração }+ \\
\text { R } \$ 2105,20\end{array}$ & - & 5,26 \\
\hline
\end{tabular}

1-o acumulado do inflacto se-refere ao periodo com a nova moeda (AS) : fukho a novernitro/ 94

2. Este indice de reajuste salarlal foi avdido da seguinte forma; $7 \%$ na Pauta Nacbonal e 3,5\% na Pauta Especifica, na qual for concedido aos emoregados um enquadramento salarial em outi 03 que proporcionou, Junto com o indice linear de 7\%, um aumento medlo de 19,70\%, Este encuadramento beneficiou 3.090 emprogados (nivel 16 a 20 ; passou pl o bivel 25 ; nivel 21 a $41: 4$ niveis; nivel 42 a $51: 3$ niveis; nivel 52 as $61: 2$ niveis; nivel 62 a $78: 1$ nivel). Apenas os gerentes nao foram contemplados com este enquadramento, recebendo somente o indice linear de $7 \%$ : 